\title{
Liquid line of descent of a basanitic liquid at 1.5 Gpa: constraints on the formation of metasomatic veins
}

\author{
Sébastien Pilet $\cdot$ Peter Ulmer $\cdot$ Samuel Villiger
}

Received: 23 January 2009/Accepted: 31 August 2009/Published online: 21 September 2009

(C) Springer-Verlag 2009

\begin{abstract}
The metasomatism observed in the oceanic and continental lithosphere is generally interpreted to represent a continuous differentiation process forming anhydrous and hydrous veins plus a cryptic enrichment in the surrounding peridotite. In order to constrain the mechanisms of vein formation and potentially clarify the nature and origin of the initial metasomatic agent, we performed a series of high-pressure experiments simulating the liquid line of descent of a basanitic magma differentiating within continental or mature oceanic lithosphere. This series of experiments has been conducted in an end-loaded piston cylinder apparatus starting from an initial hydrous ne-normative basanite at $1.5 \mathrm{GPa}$ and temperature varying between 1,250 and $980^{\circ} \mathrm{C}$. Near-pure fractional crystallization process was achieved in a stepwise manner in $30^{\circ} \mathrm{C}$ temperature steps and starting compositions corresponding to the liquid composition of the previous, higher-temperature glass composition. Liquids evolve progressively from basanite to peralkaline, aluminum-rich compositions without significant $\mathrm{SiO}_{2}$ variation. The resulting cumulates are characterized by an anhydrous clinopyroxene + olivine assemblage at high temperature $\left(1,250-1,160^{\circ} \mathrm{C}\right)$, while at lower temperature $\left(1,130-980^{\circ} \mathrm{C}\right)$, hydrous cumulates with dominantly amphibole + minor clinopyroxene, spinel,
\end{abstract}

Communicated by J. Blundy.

S. Pilet $(\bowtie)$

Institute of Mineralogy and Geochemistry,

University of Lausanne, Anthropole,

1015 Lausanne, Switzerland

e-mail: Sebastien.Pilet@unil.ch

P. Ulmer · S. Villiger

Department of Earth Sciences, ETH-Zurich,

Clausiusstrasse 25, 8092 Zurich, Switzerland ilmenite, titanomagnetite and apatite $\left(1,130-980^{\circ} \mathrm{C}\right)$ are formed. This new data set supports the interpretation that anhydrous and hydrous metasomatic veins could be produced during continuous differentiation processes of primary, hydrous alkaline magmas at high pressure. However, the comparison between the cumulates generated by the fractional crystallization from an initial ne-normative liquid or from hy-normative initial compositions (hawaiite or picrobasalt) indicates that for all hydrous liquids, the different phases formed upon differentiation are mostly similar even though the proportions of hydrous versus anhydrous minerals could vary significantly. This suggests that the formation of amphibole-bearing metasomatic veins observed in the lithospheric mantle could be linked to the differentiation of initial liquids ranging from $n e$-normative to hy-normative in composition. The present study does not resolve the question whether the metasomatism observed in lithospheric mantle is a precursor or a consequence of alkaline magmatism; however, it confirms that the percolation and differentiation of a liquid produced by a low degree of partial melting of a source similar or slightly more enriched than depleted MORB mantle could generate hydrous metasomatic veins interpreted as a potential source for alkaline magmatism by various authors.

Keywords Experimental petrology · Basanite · Metasomatism · High-pressure crystallization .

Alkaline lavas

\section{Introduction}

Cryptic and modal metasomatism of lithospheric mantle is a widespread phenomena observed in xenoliths carried to the surface by lava as well as in outcrops of mantle rocks 
(Best 1974; Dawson 1984; Francis 1976; Frey 1984; Irving 1980; Lloyd and Bailey 1975; Varne 1970; Wilshire and Trask 1971; Morris and Pasteris 1987). Although the nature and composition of metasomatic agents are debated, they are generally thought to be represented by silicate melts, carbonatite melts and/or supercritical fluids in subduction or/and intraplate context. Modal metasomatism is evidenced by the presence of newly formed phases such as pyroxenes, amphibole and phlogopite in peridotite and by the formation of hydrous and anhydrous metasomatic veins in lherzolite and harzburgite mantle rocks. In contrast, cryptic metasomatic is characterized by chemical enrichment of peridotite (phases) without the occurrence of new or additional major constituents. Various models have been proposed that relate cryptic and modal metasomatism to a continuum process (Harte et al. 1993; Nielson and Noller 1987; Nielson and Wilshire 1993; Wilshire 1987). For example, Harte et al. (1993) suggest that the percolation and differentiation of basaltic liquid across the lithosphere generates a continuum from anhydrous (pyroxene + garnet \pm olivine) to hydrous (pyroxene + amphibole \pm phlogopite) veins plus cryptic metasomatic enrichment in the adjacent peridotite. The link between vein formation and the chromatographic metasomatic enrichment in the surrounding mantle has clearly been illustrated, e.g., in outcrops of mantle rocks in the Lherz peridotite massif (Bodinier et al. 2004; McPherson et al. 1996; Woodland et al. 1996; Zanetti et al. 1996).

The metasomatic lithosphere is considered by various authors as a potential source for the generation of alkaline magmas that occur in continental and oceanic settings (Halliday et al. 1992, 1995; McKenzie and O'Nions 1995; Niu and O'Hara 2003; Pilet et al. 2004, 2005, 2008; Sun and McDonough 1989; Wass and Rogers 1980; Panter et al. 2006). Recently, Pilet et al. (2008) demonstrate that melting of hydrous metasomatic veins [hornblendite \pm clinopyroxene $(\mathrm{cpx})]$ is a viable process to reproduce the key major- and trace-element characteristics of oceanic and continental alkaline magmas. These authors suggest that the trace element pattern of hydrous metasomatic veins can be acquired by percolation and differentiation of melts produced by low-degree partial melts of peridotitic mantle similar to the depleted mantle observed below mid-ocean ridges (i.e., E-DMM to DMM; Workman and Hart 2005) across the oceanic or continental lithosphere. Even though this proposition is in agreement with the mechanism of vein formation as suggested by various authors (Harte et al. 1993; Nielson and Noller 1987; Wilshire 1987), the origin of this initial metasomatic agent is still controversial. The most widely cited mechanism for the formation of such melts infers that they are generated by low-degree partial melting of $\mathrm{H}_{2} \mathrm{O}-\mathrm{CO}_{2}$-bearing garnet peridotite (McKenzie 1989; McKenzie and O'Nions 1995;
Nielson and Noller 1987; Niu and O'Hara 2003; Wilshire 1987). The close resemblance of the relative and absolute trace element contents of metasomatic minerals (mostly amphibole) with alkaline basalt suggests that the metasomatic liquids are "OIB-like", hence inferring an alkaline nature of the metasomatic melts (Bodinier et al. 1987a; Frey 1984; Harte et al. 1993; Menzies 1983). However, low-degree partial melts from peridotite could produce liquids that are highly enriched in alkalies (particularly $\mathrm{Na}$ ) and incompatible trace elements but they could vary from highly nepheline (ne)-normative to hypersthene (hy)-normative depending on the dominant volatiles species present in the mantle source (e.g., $\mathrm{H}_{2} \mathrm{O}$ or $\mathrm{CO}_{2}$; Dasgupta and Hirschmann 2007; Gaetani and Grove 1998; Gaetani et al. 1993; Grove et al. 2006; Hirose 1997a, b; Hirose and Kawamoto 1995; Walter 1998; Wasylenki et al. 2003). Therefore, these low-degree melts do not necessarily correspond to the composition of highly ne-normative basanite, which represents the predominant primary magma type in most alkaline intra-continental magma provinces where concomitant metasomatic processes are observed in the lithosphere.

The mineralogical and chemical enrichment in peridotite associated with metasomatic vein intrusion was studied in detail in outcrops of mantle rocks (Bodinier et al. 2004; McPherson et al. 1996; Woodland et al. 1996; Zanetti et al. 1996) and in mantle xenoliths (Dawson and Smith 1988; Irving 1980; Kempton 1987; Neumann et al. 2002, 2004; Nielson and Noller 1987; Wilshire et al. 1980; WulffPedersen et al. 1999). However, the mechanism of vein formation has received less attention and is the prime target of this experimental study.

Numerous experimental studies have investigated the generation of silica-saturated and -undersaturated basaltic rocks by partial melting of peridotite (e.g., Baker and Stolper 1994; Dasgupta and Hirschmann 2007; Falloon et al. 2001; Falloon and Green 1987; Grove et al. 2006; Hirose 1997a, b; Hirose and Kushiro 1993; Holloway et al. 1992) or the phase equilibria in basaltic magmas (e.g., Baker and Eggler 1987; Bowen 1914, 1928; Grove and Bryan 1983; Jakobsson and Holloway 1986; Longhi 1991; Nielsen and Dungan 1983; O'Hara 1968; Shaw 1999; Shaw et al. 1998). However, only limited experimental data are available to trace fractional crystallization of basaltic magmas at lithospheric mantle pressures such as, for example, the experiments on an anhydrous tholeiitic basalt at 1.0 GPa (Villiger et al. 2004), on hydrous hy-normative hawaiite at $0.93 \mathrm{GPa}$ (Nekvasil et al. 2004) and experiments on hydrous picrobasalt at 1.0 and $1.5 \mathrm{GPa}$ (AlonsoPerez et al. 2009b; Kägi 2000). No data are available to date to constrain the fractional crystallization of highly $n e$-normative basaltic liquids under lithospheric conditions. In the following, we report the results of a series of 
experiments conducted in an end-loaded piston cylinder apparatus on a primitive, hydrous basanite at $1.5 \mathrm{GPa}$ and temperatures ranging between 1,250 and $980^{\circ} \mathrm{C}$. These experimental data provide constraints on the phase equilibria, and the solid and liquid compositions along the liquid line of descent of primary basanitic magmas differentiating within continental or mature oceanic lithosphere. An approximation to pure fractional crystallization was achieved using a stepwise approach as outlined in Villiger et al. (2004) and below. In summary, the liquid compositions were determined in each experiment and succeeding experiment was performed with a synthetic mix identical to the liquid (glass) composition of the previous (highertemperature) experiment. With this approach we not only simulate fractional crystallization (by removal of all solid phases), but we also obtain a series of experiments that result in variable but high-melt fractions (0.95-0.75) that, in turn, allows us to perform experiments over a large range of differentiation with the possibility to obtain precise liquid compositions. Subsequently, the liquid and cumulate composition formed by fractionation of the initial $n e$-normative liquid are compared with cumulates generated by the evolution of a hydrous hy-normative hawaiite (Nekvasil et al. 2004) and a hydrous $h y$-normative picrobasalt (Alonso-Perez et al. 2009b; Kägi 2000). This comparison allows clarification of the role of the initial melt composition on metasomatic vein formation and, potentially, provides new constraints on the mechanisms that control metasomatism by melt percolation, crystallization and reaction.

\section{Experimental and analytical techniques}

Fractional crystallization was experimentally approximated with a series of equilibrium crystallization experiment. The liquid composition was determined in each experiment and reproduced by a mixture of synthetic and natural oxides, silicates, carbonates, phosphates and hydroxides. This mixture was utilized as starting material for the subsequent experiment performed at $30^{\circ} \mathrm{C}$ lower temperature. The $30^{\circ} \mathrm{C}$ temperature increments were guided by the temperature reproducibility of the experiments that is about $\pm 15^{\circ} \mathrm{C}$

For the composition of the initial experiment reported in Table 1, a highly silica-deficient basanite (\#31; $n e+$ leucite $(L c)=22.7$ mole \% in the CIP-norm on a volatile-free basis) from the Cantal massif (Massif Central, France; Pilet et al. 2002) was selected. Its major element composition closely corresponds to nephelinite-basanite commonly observed in oceanic or continental settings. In order to investigate the crystallization of hydrous minerals, $3 \mathrm{wt} \%$ of $\mathrm{H}_{2} \mathrm{O}$ was added to the natural basanite (resulting in total
$\mathrm{H}_{2} \mathrm{O}$ of 3.35 wt $\%$ ). Basanite \#31 was cut and crushed to a size range of 1-2 $\mathrm{mm}$ and then powdered using a tungstencarbide grinder. De-ionized $\mathrm{H}_{2} \mathrm{O}$ was directly added to the starting material contained in a graphite container that was encapsulated in an outer Pt capsule and welded shut. The $\mathrm{Pt}$-graphite capsule assembly was weighed at all stages of preparation in order to monitor potential $\mathrm{H}_{2} \mathrm{O}$ loss during welding. The starting materials of the lower temperature experiments were prepared as mixtures of oxides, hydroxides, silicates, carbonates and phosphates. In a first step, mixture of $\mathrm{SiO}_{2}, \mathrm{TiO}_{2}, \mathrm{MgO}, \mathrm{Al}_{2} \mathrm{O}_{3}$ and $\mathrm{CaCO}_{3}$ were weighed, ground and homogenized in an agate mortar by hand under ethanol for $20 \mathrm{~min}$ and subsequently fired at $1,100^{\circ} \mathrm{C}$ for $2 \mathrm{~h}$ to dehydrate and decarbonate the mixture. A second mixture was prepared from $\mathrm{AlOOH}, \mathrm{Al}(\mathrm{OH})_{3}$, $\mathrm{Fe}_{2} \mathrm{SiO}_{4}$ (synthetic fayalite), $\mathrm{Na}_{2} \mathrm{SiO}_{3}, \mathrm{KAlSi}_{3} \mathrm{O}_{8}$ (natural orthoclase cleaned by fusion and re-precipitation in $\mathrm{KCl}$ ), $\mathrm{MnO}, \mathrm{Ca}_{3}\left(\mathrm{PO}_{4}\right)_{3}$ and $\mathrm{Mg}(\mathrm{OH})_{2}$. The water content of the starting material was adjusted by using variable amounts of $\mathrm{Al}_{2} \mathrm{O}_{3}, \mathrm{AlOOH}$ and $\mathrm{Al}(\mathrm{OH})_{3}$ to balance $\mathrm{Al}_{2} \mathrm{O}_{3}$ and $\mathrm{H}_{2} \mathrm{O}$. In experiments \#9 to \#11 (corresponding to experiment at $1,040-980^{\circ} \mathrm{C}$ ) where the targeted $\mathrm{H}_{2} \mathrm{O}$ contents could not be achieved using only $\mathrm{Al}$-hydroxides, $\mathrm{MgO}$ in the first mix was substituted by adding $\operatorname{Mg}(\mathrm{OH})_{2}$ to the second mix. However, in experiments \#10 and 11 , the targeted $\mathrm{H}_{2} \mathrm{O}$ contents ( 8.65 and $8.85 \mathrm{wt} \% \mathrm{H}_{2} \mathrm{O}$, respectively), could still not be achieved using $\mathrm{Al}(\mathrm{OH})_{3}$ and $\mathrm{Mg}(\mathrm{OH})_{2}$. For these two cases, we used the maximum amount of $\mathrm{H}_{2} \mathrm{O}$ that could be obtained by the addition of hydroxides ( 8.10 and $8.09 \mathrm{wt} \% \mathrm{H}_{2} \mathrm{O}$, respectively), and assumed that the total amount of $\mathrm{H}_{2} \mathrm{O}$ added in these experiments was sufficiently large that phase proportion and liquid compositions were not seriously affected by a theoretical deficit of $6-8 \% \mathrm{H}_{2} \mathrm{O}$ relative (0.55-0.60 absolute). The second mixture was ground and homogenized under ethanol for $20 \mathrm{~min}$ and dried at $110^{\circ} \mathrm{C}$. Finally, weighed proportions of mixture one and two were mixed together to obtain $2 \mathrm{~g}$ of starting material. The final powder was re-homogenized by regrinding in an agate mortar for 20 min under ethanol. For each experiment, the starting material was packed into a graphite inner capsule $(2.6 \mathrm{~mm}$ outer diameter; $1.5 \mathrm{~mm}$ inner diameter), which in turn was placed into a $3.0 \mathrm{~mm}$ OD Pt capsule. After drying the composite capsule for $>12 \mathrm{~h}$ at $110^{\circ} \mathrm{C}$, the crimped end of the Pt capsule was welded shut. The used of double capsule technique limits $\mathrm{Fe}$ loss to noble metal capsules and provides an upper limit for the $f \mathrm{O}_{2}$ at the $\mathrm{CCO}\left(\mathrm{C}-\mathrm{CO}-\mathrm{CO}_{2}\right)$ buffer equilibrium (Holloway et al. 1992; Médard et al. 2008; Ulmer and Luth 1991).

All hydrous experiments were performed in a solid media high-pressure apparatus at the Department of Earth Sciences at ETH Zürich. An end-loaded piston cylinder apparatus with a 14-mm bore was used. $\mathrm{NaCl}-\mathrm{Pyrex}-\mathrm{MgO}$ 
Table 1 Starting compositions used for the hydrous experiments

\begin{tabular}{|c|c|c|c|c|c|c|c|c|c|c|c|c|c|}
\hline & $\begin{array}{l}\text { Temperature } \\
\left({ }^{\circ} \mathrm{C}\right)\end{array}$ & $\begin{array}{l}\mathrm{SiO}_{2} \\
(\mathrm{wt} \%)\end{array}$ & $\begin{array}{l}\mathrm{Al}_{2} \mathrm{O}_{3} \\
(\mathrm{wt} \%)\end{array}$ & $\begin{array}{l}\mathrm{TiO}_{2} \\
(\mathrm{wt} \%)\end{array}$ & $\begin{array}{l}\mathrm{FeO} * \\
(\mathrm{wt} \%)\end{array}$ & $\begin{array}{l}\mathrm{MnO} \\
(\mathrm{wt} \%)\end{array}$ & $\begin{array}{l}\mathrm{MgO} \\
(\mathrm{wt} \%)\end{array}$ & $\begin{array}{l}\mathrm{CaO} \\
(\mathrm{wt} \%)\end{array}$ & $\begin{array}{l}\mathrm{Na}_{2} \mathrm{O} \\
(\mathrm{wt} \%)\end{array}$ & $\begin{array}{l}\mathrm{K}_{2} \mathrm{O} \\
(\mathrm{wt} \%)\end{array}$ & $\begin{array}{l}\mathrm{P}_{2} \mathrm{O}_{5} \\
(\mathrm{wt} \%)\end{array}$ & $\begin{array}{l}\mathrm{H}_{2} \mathrm{O} \\
(\mathrm{wt} \%)\end{array}$ & $\begin{array}{l}\text { Total } \\
\text { (wt } \%)\end{array}$ \\
\hline Run $1^{\mathrm{a}}$ & 1,250 & 40.70 & 12.82 & 3.17 & 11.80 & 0.21 & 10.39 & 11.37 & 3.52 & 1.64 & 1.03 & 3.35 & 100.00 \\
\hline Run 3 & 1,220 & 40.26 & 13.58 & 3.63 & 11.30 & 0.20 & 9.03 & 10.65 & 4.36 & 1.90 & 1.22 & 3.86 & 100.00 \\
\hline Run 4 & 1,190 & 39.78 & 14.02 & 3.76 & 11.59 & 0.20 & 8.46 & 10.31 & 4.55 & 1.99 & 1.28 & 4.06 & 100.00 \\
\hline Run 5 & 1,160 & 38.77 & 14.99 & 4.03 & 12.21 & 0.21 & 7.11 & 9.61 & 4.95 & 2.21 & 1.41 & 4.50 & 100.00 \\
\hline Run 6 & 1,130 & 37.62 & 16.08 & 4.29 & 13.06 & 0.21 & 6.09 & 8.05 & 5.51 & 2.56 & 1.26 & 5.26 & 100.00 \\
\hline Run 7 & 1,100 & 37.19 & 16.24 & 3.96 & 13.81 & 0.24 & 4.76 & 7.09 & 6.26 & 2.76 & 1.55 & 6.14 & 100.00 \\
\hline Run 8 & 1,070 & 37.33 & 16.02 & 3.86 & 13.87 & 0.25 & 4.28 & 7.11 & 6.55 & 2.69 & 1.65 & 6.39 & 100.00 \\
\hline Run 9 & 1,040 & 37.55 & 16.09 & 2.92 & 13.58 & 0.25 & 2.66 & 6.15 & 7.79 & 2.98 & 2.17 & 7.85 & 100.00 \\
\hline \multirow[t]{2}{*}{ Run 10} & 1,010 target & 38.38 & 16.23 & 2.19 & 12.87 & 0.26 & 1.78 & 5.89 & 8.73 & 2.83 & 2.20 & 8.65 & 100.00 \\
\hline & 1,010 used $^{\mathrm{b}}$ & 38.62 & 16.32 & 2.20 & 12.94 & 0.26 & 1.79 & 5.92 & 8.78 & 2.85 & 2.21 & 8.10 & 100.00 \\
\hline \multirow[t]{2}{*}{ Run 11} & 980 target & 39.80 & 16.77 & 1.87 & 12.28 & 0.26 & 1.50 & 4.89 & 9.35 & 3.00 & 1.60 & 8.67 & 100.00 \\
\hline & 980 used $^{\text {b }}$ & 39.96 & 16.84 & 1.88 & 12.33 & 0.26 & 1.51 & 5.03 & 9.38 & 3.01 & 1.71 & 8.09 & 100.00 \\
\hline
\end{tabular}

a The starting composition of Run 1 corresponds to the composition of the basanite \#31 from Cantal Massif (France; Pilet et al. 2002) with the addition of $3 \mathrm{wt} \%$ of $\mathrm{H}_{2} \mathrm{O}$

b The concentration of $\mathrm{H}_{2} \mathrm{O}$ could not be achieved in the starting material (all potential hydroxides were used; see text for explanation)

assemblies with a friction correction of $-3 \%$ applied to the nominal pressure were utilized to the highest temperatures. Pressure was calibrated against the quartz-coesite transition at $1,000^{\circ} \mathrm{C}$ and $3.07 \mathrm{GPa}$ (Bose and Ganguly 1995) and the univariant reaction fayalite + quartz $=$ orthoferrosilite at $1,000^{\circ} \mathrm{C}$ and $1.41 \mathrm{GPa}$ (Bohlen et al. 1980). Temperatures were measured with $\mathrm{Pt}-\mathrm{Pt}_{90} \mathrm{Rh}_{10}$ (S-type) and $\mathrm{Pt}_{94} \mathrm{Rh}_{6}-\mathrm{Pt}_{70} \mathrm{Rh}_{30}$ (B-type) thermocouples with an estimated accuracy of $\pm 10^{\circ} \mathrm{C}$, without taking into account the effect of pressure on the e.m.f. Experimental were run for $24 \mathrm{~h}$ and terminated by near-isobaric quench by shutting off the heating power resulting in quenching rates in the order of $200-300^{\circ} \mathrm{C} / \mathrm{s}$. In order to assess potential 'thermocouple poisoning' of the $\mathrm{Pt}-\mathrm{Rh}$ thermocouples employed, we continuously monitored the output power of the thyristor unit; the power demand was nearly constant over the duration of the experiment after an initial power increase for about 60-120 min attributed to thermal equilibration and mechanical relaxation of the assembly.

All experimental run products were analyzed using a five spectrometer electron microprobe (Cameca SX50) at the Institute of Mineralogy and Geochemistry, University of Lausanne. A $15-\mathrm{kV}$ accelerating potential, 7-nA beam current and $20-\mu \mathrm{m}$ beam size were used for analyzing the quenched glasses. All elements in the quenched glasses were analyzed for $30 \mathrm{~s}$, except for $\mathrm{Na}$ and $\mathrm{K}$ for which the counting time was $7 \mathrm{~s}$ in order to avoid potential alkali loss. The compositions of glasses are reported in Table 2. The crystalline phases were analyzed with 20-nA beam current and $1-\mu \mathrm{m}$ beam size using identical counting times. All minerals phases were re-analyzed "a posteriori" using a JEOL JXA-8200 (5 spectrometer) electron microprobe at University of Lausanne. The improved electronic image of the JEOL microprobe with respect to the older Cameca microprobe allowed a more precise selection of optimal analysis locations on the samples. However, no significant variation was observed in mineral compositions between both series of analyses; the compositions of minerals reported in Table 2 correspond to the averages of all analyses.

In contrast to equilibrium crystallization experiments, where every single experiment is independent of the other, in fractional crystallization experiments, all experiments are linked. The analyzed glass compositions directly determine the composition of the starting material of the next experiment performed at $30^{\circ} \mathrm{C}$ lower temperature. Therefore, the determination of glass compositions is critical. Various parameters could critically influence microprobe analyses of experimental hydrous glasses. For the case of hydrous glass, the total sum is depends on (1) the quality of the polished surface, (2) potential water loss and (3) the adequacy of microprobe standards and the correction procedure to analyze glassy materials. Consequently, we avoided the estimation of water contents in glasses by using the difference of the sum of oxides versus $100 \%$. Except for run \#1 where the mass balance calculated using all elements (except $\mathrm{FeO}^{*}$ ) results in a good fit and where the microprobe data were used to estimate the composition of the starting composition for the next run, we recalculate the liquid composition using the following technique: first, we calculated the proportion of minerals that crystallized by mass balance utilizing all major elements except $\mathrm{SiO}_{2}$ and $\mathrm{FeO}^{*}$ that could be affected by $\mathrm{Fe}$ loss. $\mathrm{SiO}_{2}$ was excluded from the mass balance calculation because the $\mathrm{SiO}_{2}$ contents measured in the glasses resulted in significantly higher concentration than expected from 


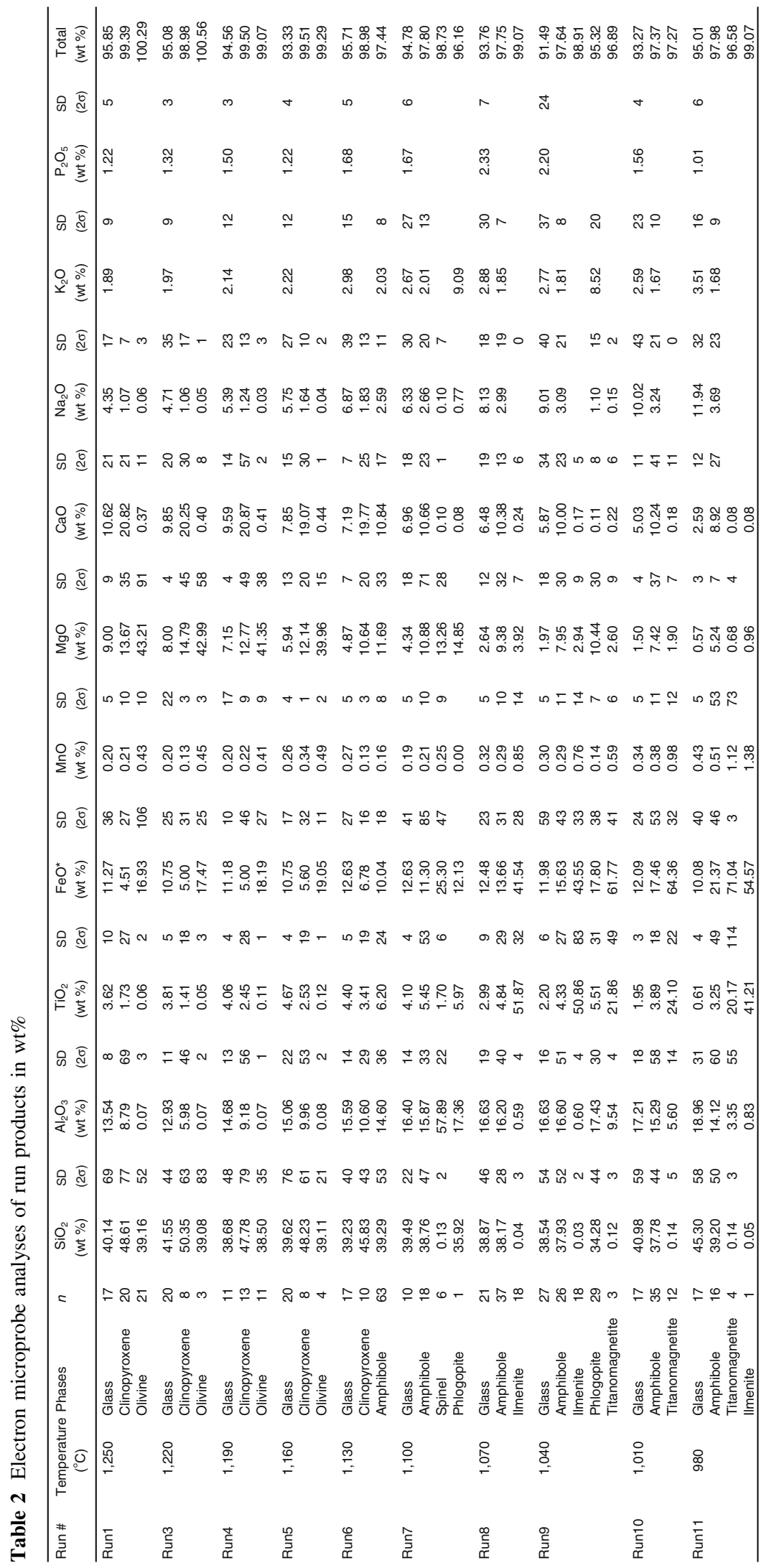


mass balance calculation using analyzed mineral and the initial starting compositions. We interpret this $\mathrm{SiO}_{2}$ increase (3 wt $\%$ on average) as the result of a potential contamination by the agate mortar during homogenization of the oxide/silicate mix and/or by analytical problem related to the distinctly different matrix composition between the standard used for $\mathrm{SiO}_{2}$ calibration (anorthite) and the silicate-glasses in the experiments. The $\mathrm{H}_{2} \mathrm{O}$ contents of the glasses were considered as a free parameter in the calculation (i.e., during each mass balance calculation the sum of the oxides in the bulk was constrained to be 100 minus $\mathrm{FeO}^{*}$ and $\mathrm{SiO}_{2}$, and thus as bulk $\mathrm{H}_{2} \mathrm{O}$ increased the remaining oxides decreased proportionately). The sums of the residuals squared for these mass balance calculations are reported in Table 3. From the mass balance calculations, we recalculate the liquid composition including $\mathrm{H}_{2} \mathrm{O}$, $\mathrm{FeO}^{*}$ and $\mathrm{SiO}_{2}$ content using the calculated mineral fractions, the compositions of the minerals and the starting material. This calculated composition represents the starting material of the next run that is reported in Table 1.

In order to test potential water loss in our experiments, we measure the $\mathrm{H}_{2} \mathrm{O}$ (and $\mathrm{CO}_{2}$ ) contents of the glass of run \#3 $\left(1,220^{\circ} \mathrm{C}\right)$ by Fourier-transform infrared spectroscopy (FTIR) at the California Institute of Technology using the analytical approach reported by (Dixon et al. 1995) and the parameters given in Pilet et al. (2008). The measured volatile content (3.76 wt $\%$ composed of $2.58 \mathrm{wt} \% \mathrm{H}_{2} \mathrm{O}$ and $1.18 \mathrm{wt} \% \mathrm{CO}_{2}$ ) was close to the total amount of volatile (reported as $\mathrm{H}_{2} \mathrm{O}$ in Table 1) calculated in the melt by the method described previously $\left(3.86 \mathrm{wt} \% \mathrm{H}_{2} \mathrm{O}\right)$. This suggests that the $\mathrm{H}_{2} \mathrm{O}$ loss was limited in our experiments; similar observation has been made by Pilet et al. (2008) for hydrous experiments using hornblendite as starting material and Pt-graphite double capsules. The $\mathrm{CO}_{2}$ observed in experiment \#3 (and probably in all experiments) are produced by the equilibrium reaction between the graphite inner capsule and the melt at the $f \mathrm{O}_{2}$ of each experiment. This $\mathrm{CO}_{2}$ content $(1.18 \mathrm{wt} \%)$ is in agreement with the range of $\mathrm{CO}_{2}$ content $\left(0.6-1.21\right.$ wt $\left.\% \mathrm{CO}_{2}\right)$ measured in hydrous experiments at $1.5 \mathrm{GPa}$ by Pilet et al. (2008). These authors indicate that the $\mathrm{CO}_{2}$ content in experimental glasses are uncorrelated with melt fraction. Furthermore, the presence of $\mathrm{CO}_{2}$ along the liquid line of descent of an initial basanitic melts is expected (e.g., metasomatism process is assumed to be associated with the presence of $\mathrm{CO}_{2}$ ), and since dissolved $\mathrm{CO}_{2}$ likely influences the phase equilibrium results, its presence in our experiments is realistic but unconstrained.

The $\mathrm{Fe}$ loss in the present experiments was evaluated using the difference of $\mathrm{FeO}^{*}$ in the analyzed glass (Table 2) compared with the recalculated composition not considering $\mathrm{FeO}^{*}$ during mass balance calculation (Table 1). It varies from $6.64 \%$ in experiment \#10 to

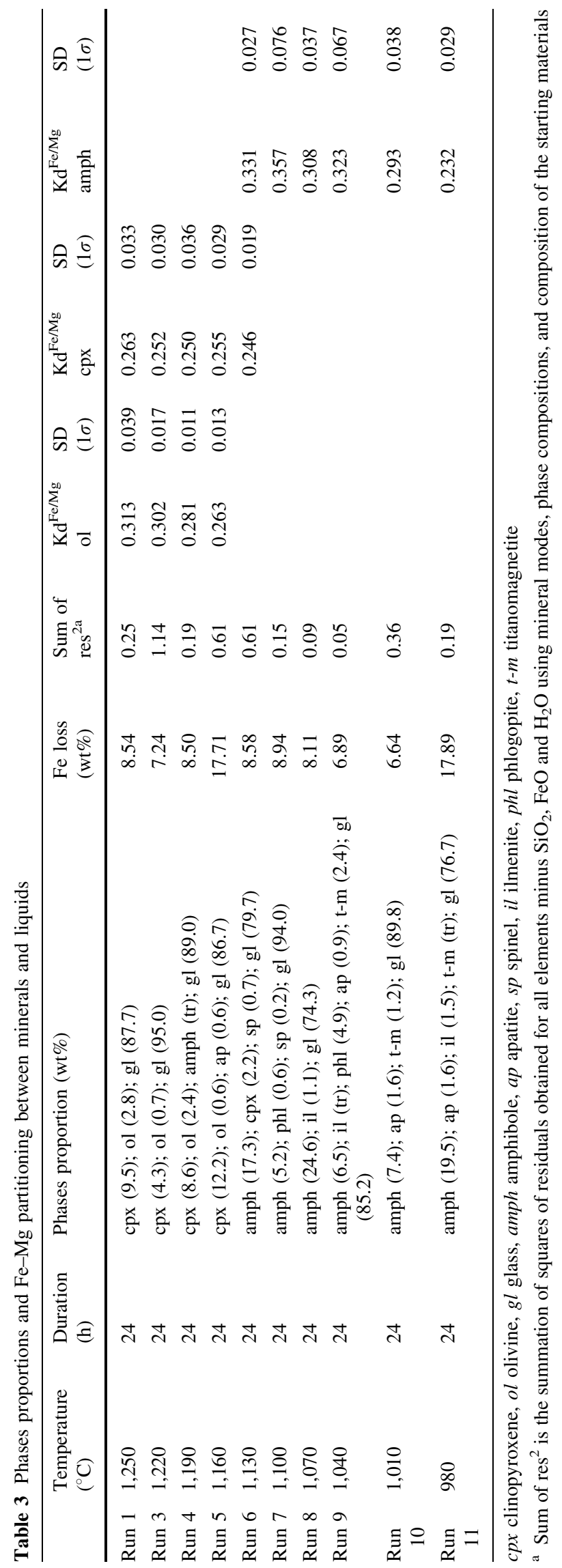


$17.9 \%$ in experiment \#11 with an average of $9.9 \%$ (Table 3). Fe was probably lost to the platinum capsule via small cracks in the inner graphite capsule. These amounts of Fe loss should not result in serious deviations from the differentiation trend as the method employed to calculate the liquid compositions compensate these losses (except for run \#1 where the composition of the starting material for run \#3 corresponded to the analyzed liquid of run \#1).

An evaluation of $\mathrm{Fe}-\mathrm{Mg}$ partitioning between minerals and liquids $\left[\mathrm{Kd}_{\mathrm{Fe}^{*}-\mathrm{Mg}}^{\min -\mathrm{liq}}\right.$ where $\mathrm{Kd}_{\mathrm{Fe}^{*}-\mathrm{Mg}}^{\min -\mathrm{liq}}=\left(\mathrm{FeO}^{\mathrm{min}} / \mathrm{FeO}^{*-}\right.$ $\left.\left.{ }^{\mathrm{liq}}\right) /\left(\mathrm{Mg}^{\mathrm{min}} / \mathrm{MgO}^{\mathrm{liq}}\right)\right]$ can be utilized to test attainment of equilibrium in the experiments. The calculated $\mathrm{Kd}_{\mathrm{Fe}^{*}-\mathrm{Mg}}^{\min -\mathrm{liq}}$ for olivine, cpx and amphibole are reported in Table 3 . Figure 1a compares the variation of $\mathrm{Kd}_{\mathrm{Fe}^{*}-\mathrm{Mg}}^{\mathrm{ol}}$ versus the total alkali content of the coexisting glasses from our experiments with $\mathrm{Kd}_{\mathrm{Fe}^{*}-\mathrm{Mg}}^{\mathrm{ol}-\mathrm{liq}}$ measured in various experiments where olivine coexist with melts (references in Wasylenki et al. 2003). The $\mathrm{Kd}_{\mathrm{Fe}^{*}-\mathrm{Mg}}^{\mathrm{ol}-\mathrm{miq}}$ measured in our experiments is in good agreement with those of other experiments if the total alkali content of glass is taken into account. The general decrease of $\mathrm{Kd}_{\mathrm{Fe}^{*}-\mathrm{Mg}}^{\mathrm{ol}-\mathrm{gi}}$ with increasing alkali content of the melt phase was explained by increasing $\mathrm{Fe}^{3+} / \mathrm{Fe}^{2+}$ ratios in silicate melts at constant pressure and $f \mathrm{O}_{2}$ with increasing alkali contents (e.g., Sack et al. 1980; Wasylenki et al. 2003). In addition, the $\mathrm{Fe}^{2+}$ $\mathrm{Mg}$ olivine-liquid exchange reaction appears to be sensitive to bulk composition too (Gee and Sack 1988; Kushiro and Mysen 2002). The range of $\mathrm{Kd}_{\mathrm{Fe}^{*}-\mathrm{Mg}}^{\mathrm{cpx}-\mathrm{liq}}$ and $\mathrm{Kd}_{\mathrm{Fe}^{*}-\mathrm{Mg}}^{\mathrm{amph}-\mathrm{liq}}$ measured in our experiments are in good agreement with those from other experiments (Fig. 1b, c) and, consequently, we suggest that we closely approached equilibrium conditions in our experiments.

\section{Results}

All experiments present large proportion of liquid ( $>74 \%)$ associated with automorphic crystals with size varying between 2 and $\sim 20 \mu \mathrm{m}$. No evidence for a free fluid phase is observed in any experimental charge (absence of bubbles in glasses or lack of puffed capsules); thus all experiments are considered to represent fluid-absent conditions.

\section{Liquids}

The evolution of liquid compositions as a function of temperature is presented in Fig. 2 that additionally illustrates the differences between the recalculated liquid compositions and the analyzed glass compositions. A close correspondence between recalculated liquid and analyzed glass compositions is evident for most elements except $\mathrm{SiO}_{2}, \mathrm{FeO}^{*}$ and $\mathrm{H}_{2} \mathrm{O}$, which are, however, not used in the mass balance calculation. As indicated previously, the
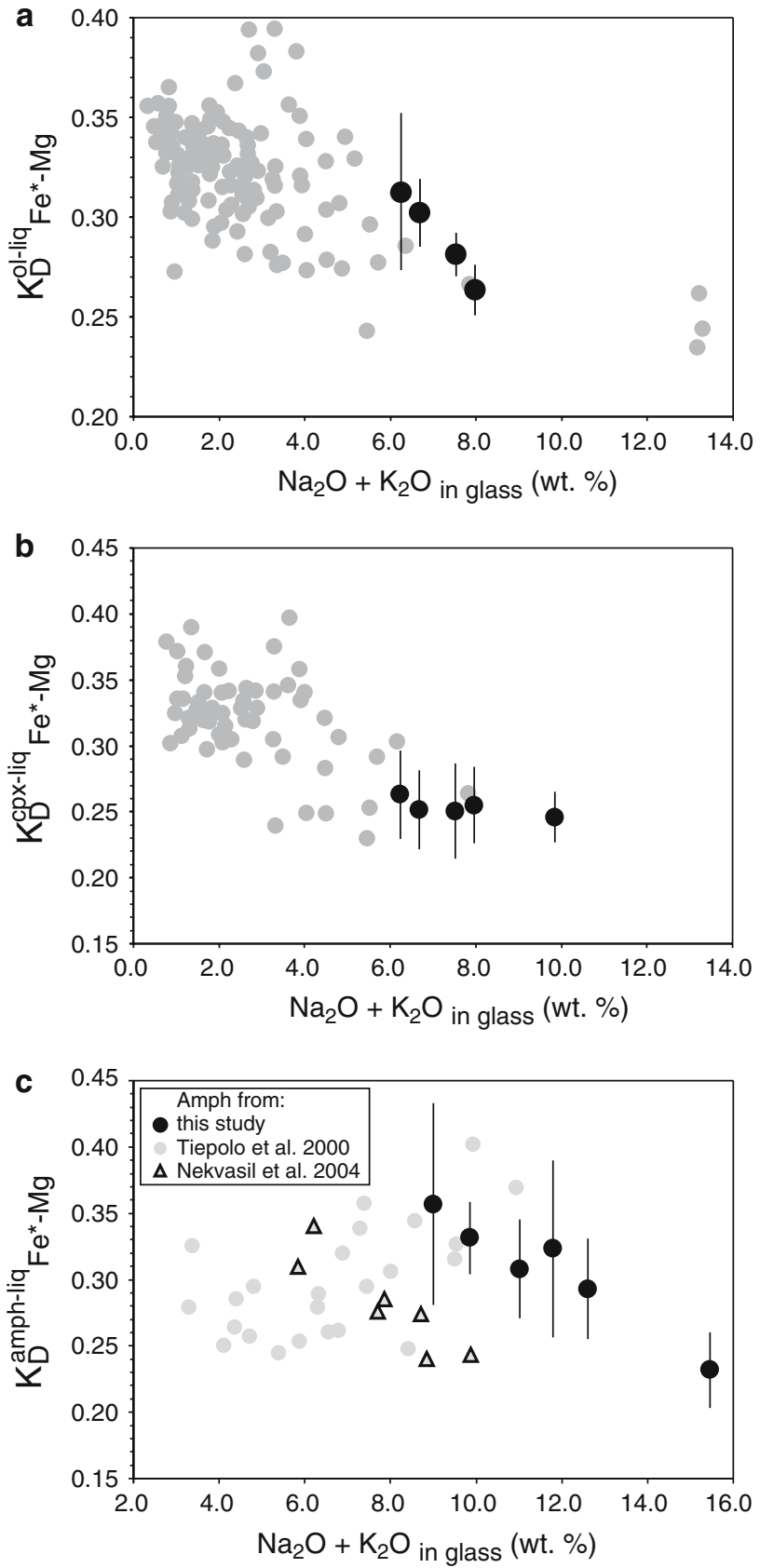

Fig. $1 \mathrm{Fe}^{*}-\mathrm{Mg}$ partitioning $\left[\mathrm{Kd}_{(\mathrm{Fe}-\mathrm{Mg})}^{\min -\mathrm{liq}}=(\mathrm{Fe} / \mathrm{Mg})^{\text {solid }} /(\mathrm{Fe} / \mathrm{Mg})^{\text {liquid }}\right]$ between crystals and liquid for $\mathbf{a}$ olivine, $\mathbf{b}$ clinopyroxene and c amphibole as a function of the total alkali content $\left(\mathrm{Na}_{2} \mathrm{O}+\right.$ $\mathrm{K}_{2} \mathrm{O}$ wt $\%$ on a anhydrous basis) of the liquid. Black circles $\mathrm{Kd}$ from basanite FC experiments (this study) with their standard deviations $(1 \sigma)$; grey circles in $\mathbf{a}$ and $\mathbf{b}$ compositions of olivine, cpx and liquid taken from various melting experiments [Wasylenki et al. (2003) and references therein]; grey circles in c amphibole and liquid compositions taken from Tiepolo and (2000) from an equilibrium crystallization study; open black diamonds amphiboles taken from Nekvasil et al.'s (2004) fractional crystallization study on a initial hawaiite composition

difference of $\mathrm{SiO}_{2}$ seems related to potential contamination or/and microprobe analytical problems while the lower $\mathrm{FeO}^{*}$ contents in analyzed glasses relative to the 
recalculated composition is attributed to $\mathrm{Fe}$ loss. The $\mathrm{H}_{2} \mathrm{O}$ content of glasses reported in Fig. $2 j$ was calculated from the difference of the total sum of oxides to $100 \%$. Overall, considering all potential problems involved in this method, the water contents obtained by the difference method and from the recalculated melt composition $(<30 \%)$ seem acceptable, and more significantly do not reveal any systematic $\mathrm{H}_{2} \mathrm{O}$ gains or losses in the experimental charges. The liquid evolution is controlled by the mineralogy of the fractionating assemblage, which varies from clinopyroxene + olivine (olivine-clinopyroxenites) at temperature ranging from $1,250-1,160^{\circ} \mathrm{C}$ to mostly pure hornblendite ( $>90 \%$ amphibole) at temperature below $1,130^{\circ} \mathrm{C}$. The $\mathrm{Al}_{2} \mathrm{O}_{3}, \mathrm{Na}_{2} \mathrm{O}$ and $\mathrm{K}_{2} \mathrm{O}$ contents in the residual liquids constantly increase with decreasing temperature (or increasing degree of differentiation), whereas $\mathrm{CaO}$ and $\mathrm{MgO}$ contents continuously decrease. $\mathrm{SiO}_{2}$ and $\mathrm{TiO}_{2}$ contents indicate more complicated trends as a function of temperature. The $\mathrm{SiO}_{2}$ content initially slightly decrease from 1,250 to $1,130^{\circ} \mathrm{C}$ followed by a slight increase below $1,130^{\circ} \mathrm{C}$. $\mathrm{TiO}_{2}$ contents, on the other hand, slightly rise from 1,250 to $1,130^{\circ} \mathrm{C}$ followed by a strong decrease below $1,130^{\circ} \mathrm{C}$. Highly differentiated liquid compositions $(\mathrm{MgO}<2 \mathrm{wt} \%)$ were generated below $1,040^{\circ} \mathrm{C}$ and are characterized by peralkaline composition (containing between 1.2 and 3.8 mole\% of $\mathrm{Na}_{2} \mathrm{SiO}_{3}$ in the CIPW norm calculations). The liquid composition produced at $980^{\circ} \mathrm{C}$ is characterized by low $\mathrm{MgO}$ content $(>1 \mathrm{wt} \%)$, low $\mathrm{FeO}_{\text {tot }}$ content, but high $\mathrm{Na}_{2} \mathrm{O}, \mathrm{K}_{2} \mathrm{O}$ and $\mathrm{Al}_{2} \mathrm{O}_{3}$ contents.

\section{Cumulates}

Figure 3 depicts the evolution of (theoretical) cumulates as a function of temperature (the term cumulates is taken equal to segregates in this contribution). At temperatures between 1,250 and $1,160^{\circ} \mathrm{C}$, the cumulates are anhydrous with cpx forming the principal phase accompanied by minor olivine (cpx:ol $\sim 4: 1$ ). Olivine disappears from the cumulate assemblage at $1,160^{\circ} \mathrm{C}$. At $1,130^{\circ} \mathrm{C}$, amphibole starts to crystallize and becomes the dominant cumulate phase until $980^{\circ} \mathrm{C}$. Amphibole and cpx coexist only in cumulates formed at $1,130^{\circ} \mathrm{C}$. Phlogopite is observed as a quench phase in all experiments performed at temperature below $1,190^{\circ} \mathrm{C}$. However, their size was too small to be analyzed except in runs \#7 and \#9 $\left(1,100\right.$ and $\left.1,040^{\circ} \mathrm{C}\right)$ where phlogopite forms large crystals with poikilitic texture surrounding automorphic crystals of amphibole. This suggests that phlogopite must be considered rather as a quench phase then a stable phase that forms close to the solidus upon quenching. On the other hand, mass balance calculations of runs \#7 and \#9 require the presence of phlogopite in order to explain the $\mathrm{K}_{2} \mathrm{O}$ content of the glass; this implies that the glass compositions measured in the experiments were actually modified by quenching. Consequently, we included phlogopite in the cumulate assemblages that are reported in Fig. 3.

\section{Mineral compositions}

Clinopyroxene and amphibole, which are present between 1,250 and $1,130^{\circ} \mathrm{C}$ and from 1,130 to $980^{\circ} \mathrm{C}$, respectively, are the most abundant phases that crystallize in these experiments. Their compositions show a systematic decrease of $\mathrm{Mg} \#\left(=\mathrm{Mg} / \mathrm{Mg}+\mathrm{Fe}^{\text {tot }} \times 100\right)$ with the evolution of the liquid (Table 2).

The $\mathrm{Al}_{2} \mathrm{O}_{3}$ and $\mathrm{TiO}_{2}$ content in clinopyroxenes (augite following the cpx nomenclature of Morimoto 1988) increase with decreasing temperature while the $\mathrm{Al} / \mathrm{Ti}$ ratio in cpx decreases as well as the $\mathrm{Kd}_{\mathrm{Al} / \mathrm{Ti}}^{\mathrm{cp} / \mathrm{liq}}$ (the composition of cpx in experiment \#3 shows significantly lower $\mathrm{Al}_{2} \mathrm{O}_{3}$ and $\mathrm{TiO}_{2}$ content than cpx in other experiment; it is not clear if it is a real effect or an experimental problem). $\mathrm{The}^{\mathrm{TiO}}{ }_{2}$ increase of cpx is in agreement with the evolution of cpx composition observed in (alkaline) differentiation series (e.g., Yagi and Onuma 1967). The increase of $\mathrm{Al}_{2} \mathrm{O}_{3}$ in cpx is primarily controlled by increasing CaTs substitution $\left(\mathrm{CaAl}_{2} \mathrm{SiO}_{6}\right)$ combined with $\mathrm{Ti}-\mathrm{CaTs}$ substitution $\left[\mathrm{Si}_{2}^{[4]} \mathrm{Mg}^{[6]}=\mathrm{Al}_{2}^{[4]} \mathrm{Ti}^{[6]}\right.$ associated with a decrease of the $\mathrm{SiO}_{2}$-activity in the coexisting liquids (Carmichael et al. 1970)]. The $\mathrm{Na}_{2} \mathrm{O}$ content of cpx exhibits a clear increase with decreasing temperature that is associated with an increase of $\mathrm{Al}_{2} \mathrm{O}_{3}$ and $\mathrm{FeO} *$; it is, however, not clear if this $\mathrm{Na}$ increase is related to an increase of jadeite $\left(\mathrm{NaAlSi}_{2} \mathrm{O}_{6}\right)$ or aegirine components $\left(\mathrm{NaFe}^{3+} \mathrm{Si}_{2} \mathrm{O}_{6}\right)$. Nevertheless, the correlation of the $\mathrm{Na}$ content in cpx with the alkalinity index $\left(=\right.$ molar $\left.\left(\mathrm{Na}_{2} \mathrm{O}+\mathrm{K}_{2} \mathrm{O}\right) / \mathrm{Al}_{2} \mathrm{O}_{3}\right)$ suggests that an aegirine component substitution is a potential mechanism for the Na increase observed in our experiment.

Amphiboles are titanian-potassian kaersutites following the classification scheme of Leake et al. (1997) and reveal increasing $\mathrm{Na}_{2} \mathrm{O}$ and decreasing $\mathrm{TiO}_{2}, \mathrm{CaO}, \mathrm{SiO}_{2}$ with decreasing $\mathrm{Mg \#}$, i.e., with increasing differentiation of the liquid from which amphibole crystallized (Fig. 4). The variation of $\mathrm{TiO}_{2}, \mathrm{CaO}, \mathrm{Na}_{2} \mathrm{O}$ contents in amphibole partly correlate with the compositions of the coexisting liquid. However, the calculated $\mathrm{Kd}^{\text {amph/liq }}$ for $\mathrm{TiO}_{2}$ shows significant variations (Fig. 5a) and decreases with increasing temperature (decreasing $\mathrm{TiO}_{2}$ content of the coexisting liquid; Fig. 5a). The $\mathrm{K}_{2} \mathrm{O}$ content in amphibole exhibits a moderate decrease with decreasing Mg\# (Fig. 4f). This trend is actually anti-correlated with the variation observed in the residual liquids that shows an increase of the $\mathrm{K}_{2} \mathrm{O}$ content with decreasing $\mathrm{Mg \#}$ or temperature (Fig. 2h). These Kd-relationships suggests that for $\mathrm{K}_{2} \mathrm{O}$ (and to a smaller degree for $\mathrm{TiO}_{2}$ ) minor element partitioning behavior is not constant or primarily controlled by their 


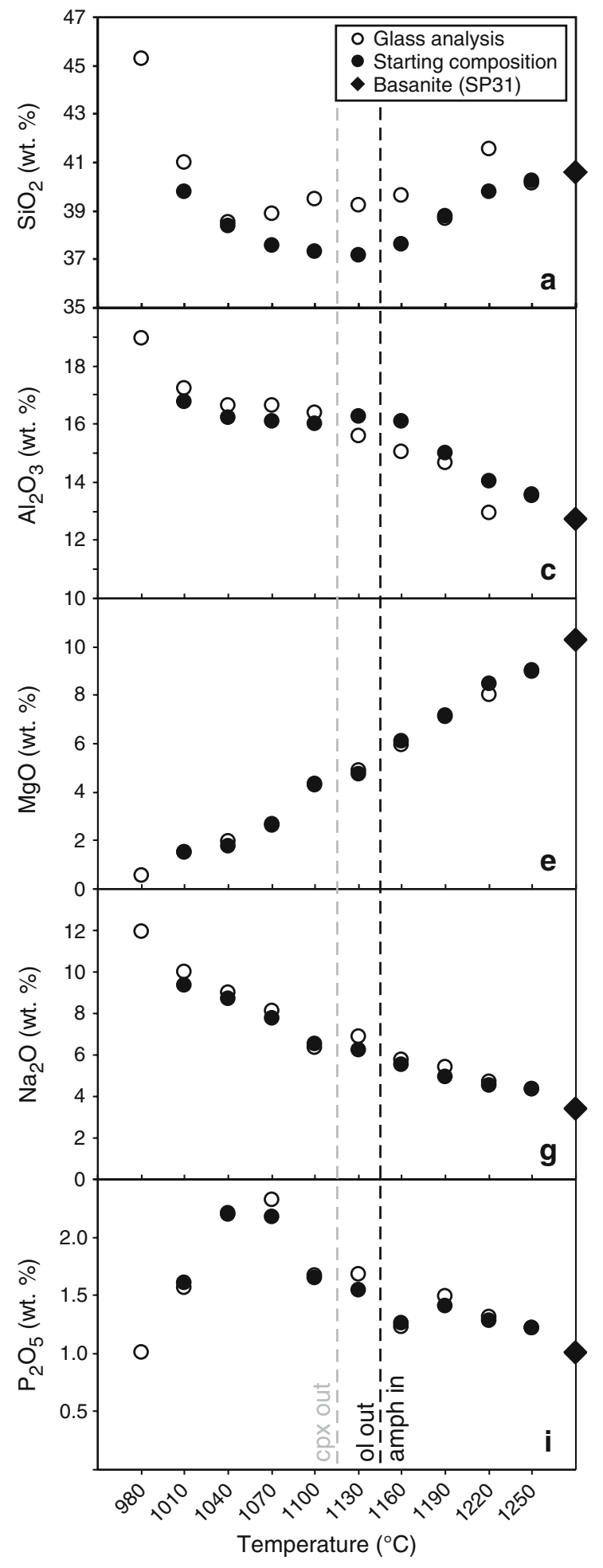

Fig. 2 Variation of selected oxides (in wt $\%$ ) of the liquids produced by fractional crystallization of an initial basanite as a function of temperature. a $\mathrm{SiO}_{2}, \mathbf{b} \mathrm{TiO}_{2}, \mathbf{c ~} \mathrm{Al}_{2} \mathrm{O}_{3}, \mathbf{d ~ F e O} *$ (=total $\mathrm{Fe}$ as $\mathrm{FeO}$ ), e $\mathrm{MgO}$, f CaO, $\mathbf{g ~ N a}{ }_{2} \mathrm{O}, \mathbf{h ~} \mathrm{K}_{2} \mathrm{O}$, i $\mathrm{P}_{2} \mathrm{O}_{5}$, and $\mathbf{j} \mathrm{H}_{2} \mathrm{O}$. The appearance (in) of amphibole or disappearance (out) of olivine (ol) and

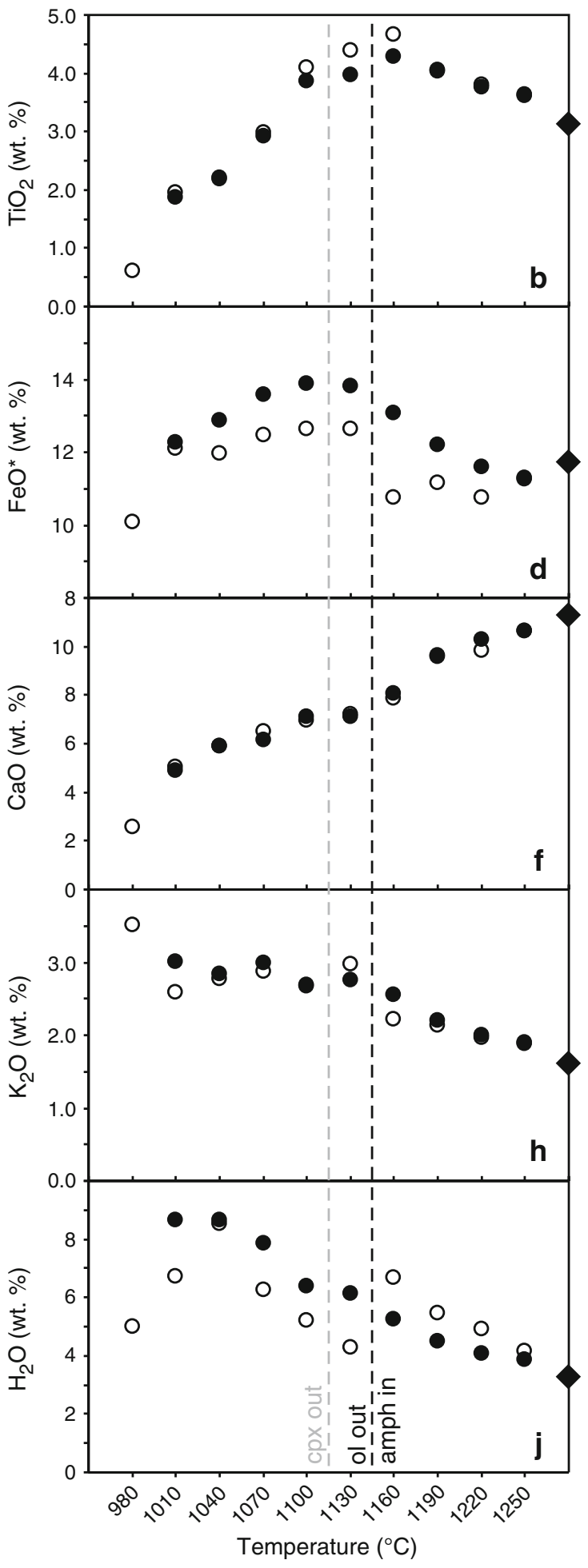

clinopyroxene ( $c p x)$ are denoted by vertical lines along the liquid lines of descent. The starting compositions correspond to the recalculated glass compositions of the previous runs (see text for details on the recalculation of experimental liquid compositions) 


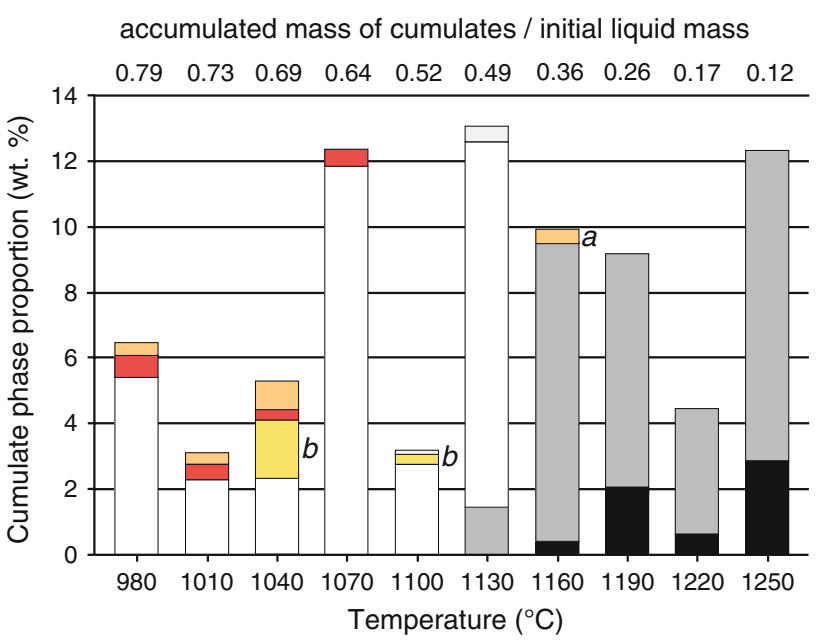

\begin{tabular}{|c|c|c|}
\hline olivine & $\square$ amphibole & $\square$ apatite \\
\hline$\square$ clinopyroxene & $\square$ phlogopite & $\square$ ilmenite + titanomagnetite \\
\hline
\end{tabular}

Fig. 3 Schematic representation of calculated modal compositions (in wt $\%$ ) of cumulates (crystallisates) generated during the fractional crystallization experiments from an initial basanite as a function of temperature. Top labels indicate the accumulated fraction of solids relative to the starting composition (basanite \#31). $a$ The amount of apatite reported in run $\# 4\left(1,160^{\circ} \mathrm{C}\right)$ is inferred from mass balance calculation but apatite has not actually been observed in the experimental charge. $b$ Phlogopite reported in run $\# 6\left(1,040^{\circ} \mathrm{C}\right)$ and \#8 $\left(1,100^{\circ} \mathrm{C}\right)$ display poikilitic texture enclosing amphibole; these crystals are considered to represent quench crystals rather than phase stable at the $P-T$ conditions of the experiment (see text for further explanation)

activities in the liquid phase, but either strongly controlled by mineral structure constraints and/or physical parameters (e.g., temperature, pressure or degree of polymerization of the coexisting liquid).

Apatite is observed in runs $\# 9$ to $\# 11\left(1,040-980^{\circ} \mathrm{C}\right)$. However, crystal sizes are too low to obtain correct EMP analyses. Therefore, we have assumed a stoichiometric composition of apatite for the mass balance calculation. Moreover, the concentration of $\mathrm{P}_{2} \mathrm{O}_{5}$ in the liquid in run \#5 $\left(1,160^{\circ} \mathrm{C}\right)$ suggests that apatite crystallized, but no apatite has been directly identified in this run.

Aluminous spinels are observed in runs \#6-7. However, regarding the fact that $\mathrm{Cr}_{2} \mathrm{O}_{3}$ was not contained in the starting materials, spinel composition obtained in this study cannot directly be compared to spinels from natural rocks. At temperatures equal to and below $1,070^{\circ} \mathrm{C}, \mathrm{Fe}-\mathrm{Ti}$ oxide phases are present and form the association ilmenite \pm titanomagnetite. This assemblage allowed the calculation of the oxygen fugacity for run $\# 9\left(1,040^{\circ} \mathrm{C}\right)$ and $\# 11\left(980^{\circ} \mathrm{C}\right)$.

The $f \mathrm{O}_{2}$ in $\mathrm{Pt}$-graphite double capsule experiments is imposed by the equilibrium between graphite and the sample material. Experiments where $\mathrm{H}_{2} \mathrm{O}$-rich $\mathrm{C}-\mathrm{O}-\mathrm{H}$ fluid coexists with melt have shown that the $\mathrm{fO}_{2}$ was constrained by the graphite- $\mathrm{COH}$ fluid equilibrium to about $0.5 \log$ units $( \pm 0.1)$ below the CCO buffer (Ulmer and Luth 1991). In fluid-absent systems, Holloway et al. (1992) indicate that the $\mathrm{fO}_{2}$ is controlled by the reaction between $\mathrm{Fe}_{2} \mathrm{O}_{3}$ in the melt with graphite through the reaction $\mathrm{C}+2 \mathrm{Fe}_{2} \mathrm{O}_{3}=\mathrm{CO}_{2}+4 \mathrm{FeO}$ and, that the $\mathrm{CCO}$ buffer corresponds to a maximum $f \mathrm{O}_{2}$ value in experiment using Pt-graphite capsule. A $f \mathrm{O}_{2}$ of $\mathrm{CCO}, 0.8 \pm 0.3$ was estimated by Médard et al. (2008) for Pt-graphite experiments relevant for nominally anhydrous mantle-melting. Nevertheless, the $f \mathrm{O}_{2}$ in $\mathrm{H}_{2} \mathrm{O}$-rich, but fluid-undersaturated experiments are less well constrained; however, all aforementioned authors agree (Ulmer and Luth 1991; Holloway et al. 1992; Médard et al. 2008) that the CCO buffer correspond to an upper limit for the $f \mathrm{O}_{2}$ in such experiments and that the actual $f \mathrm{O}_{2}$ is less than $0.5 \log$ units below this value for $\mathrm{H}_{2} \mathrm{O}$-rich experiments.

The $f \mathrm{O}_{2}$ calculated for run \#9 using the excel spreadsheet provided by Sauerzapf et al. (2008) result in an $\log _{10}$ $f \mathrm{O}_{2}$ of -11.12 corresponding to $\triangle \mathrm{NNO}-1.23$ and a temperature of $993^{\circ} \mathrm{C}$. The compositions of ilmenite and titanomagnetite in run \#11 are outside the compositional field used to calibrate the oxybarometer of Sauerzapf et al. (2008) and, consequently, do not result in reliable data. The $f \mathrm{O}_{2}$ value of $\mathrm{NNO}-1.23$ is about $0.25 \log$ units below the $\mathrm{C}-\mathrm{CO}_{2}-\mathrm{CO}$ equilibrium (the $\mathrm{fO}_{2}$ of the $\mathrm{CCO}$ equilibrium was calculated using parameters from Jakobsson and Oskarsson (1994) and the calculated temperature of $993^{\circ} \mathrm{C}$ ) and, hence, very close to the estimated $f \mathrm{O}_{2}$ conditions in graphite capsule with a $\mathrm{C}-\mathrm{O}-\mathrm{H}$ fluid dominated by $\mathrm{H}_{2} \mathrm{O}$ and $\mathrm{CO}_{2}$ thereby confirming that the employment of graphite capsules in hydrous experiments indeed control $f \mathrm{O}_{2}$ close to, but slightly below the $\mathrm{C}-\mathrm{CO}_{2}-\mathrm{CO}$ equilibrium.

\section{Discussion}

Evolution of residual liquid compositions

Figure 6 compares the low-pressure differentiation trends of alkaline basalts observed in the Cantal massif with the experimental trend produced from a basanite starting composition differentiating at lithospheric mantle pressure. The experimental liquids show a initial decrease of $\mathrm{SiO}_{2}$ content which is distinct from the slight increase observed in lowpressure alkaline differentiation trends or the trend reproduced experimentally for an hawaiite composition (Nekvasil et al. 2004) (Fig. 6a). These distinct differences are attributed to different proportion of ol and cpx that crystallize/ fractionate at different pressure conditions. The effects of $10 \%$ olivine or $20 \% \mathrm{cpx}$ fractionation from the initial composition are indicated in Fig. 6 by arrows to emphasize the distinct effect of these phases on the liquid evolution 


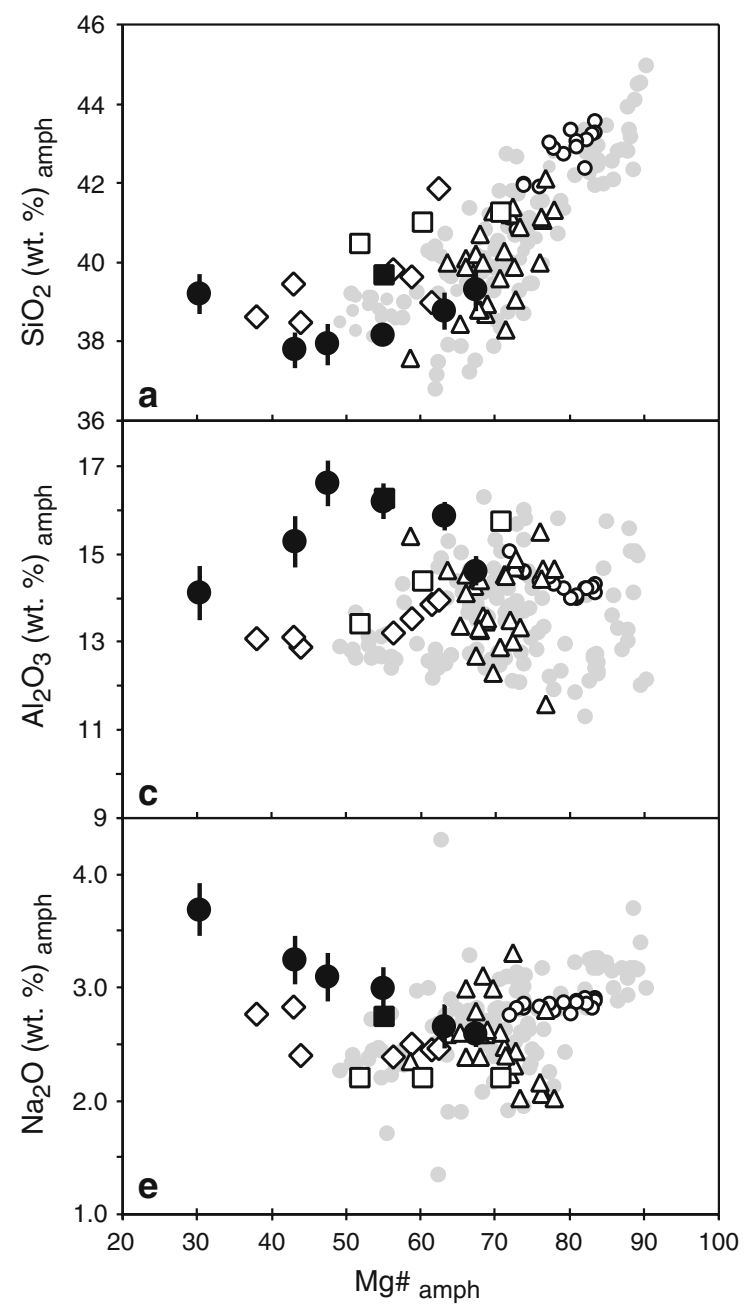

Fig. 4 Variation of amphibole compositions as a function of $\mathrm{Mg \#}$ from the basanite experiments (this study, filled black circles) compared with amphiboles from FC experiment starting from an hawaiite at $0.93 \mathrm{GPa}$ (open black diamond; Nekvasil et al. 2004) and a picrobasalt at $1.5 \mathrm{GPa}$ (filled black square; Alonso-Perez et al. $2009 \mathrm{~b}$ ) and at $1.0 \mathrm{GPa}$ (open black squares; Kägi 2000). a $\mathrm{SiO}_{2}$, b $\mathrm{TiO}_{2}$, c $\mathrm{Al}_{2} \mathrm{O}_{3}$, d $\mathrm{CaO}$, e $\mathrm{Na}_{2} \mathrm{O}$ and $\mathbf{f} \mathrm{K}_{2} \mathrm{O}$. The composition of

behavior. The initial decrease of silica in the experimental liquid between 1,250 and $1,130^{\circ} \mathrm{C}$ is a consequence of the dominant fractionation of $\mathrm{cpx}\left(\mathrm{SiO}_{2}{ }^{\mathrm{cpx}}>45 \mathrm{wt} \%\right)$ rather then olivine $\left(\mathrm{SiO}_{2}{ }^{\mathrm{ol}}<40 \mathrm{wt} \%\right)$. The larger proportion of cpx versus olivine is consistent with the contraction of the olivine stability field with increasing pressure (O'Hara 1968). The proportion of cpx relative to olivine in the fractionating assemblage does not significantly modify the evolution of the residual liquid in $\mathrm{Al}_{2} \mathrm{O}_{3}, \mathrm{TiO}_{2}, \mathrm{Na}_{2} \mathrm{O}, \mathrm{K}_{2} \mathrm{O}$, and $\mathrm{P}_{2} \mathrm{O}_{5}$ contents; fractionation of both minerals results in an increase of these elements in residual liquids. A major difference is observed for the behavior of $\mathrm{Mg}(\mathrm{MgO}$ or

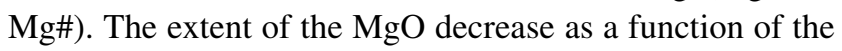
proportion of fractionated phases varies significantly between olivine and cpx. Figure 6 reveals that 10\% olivine

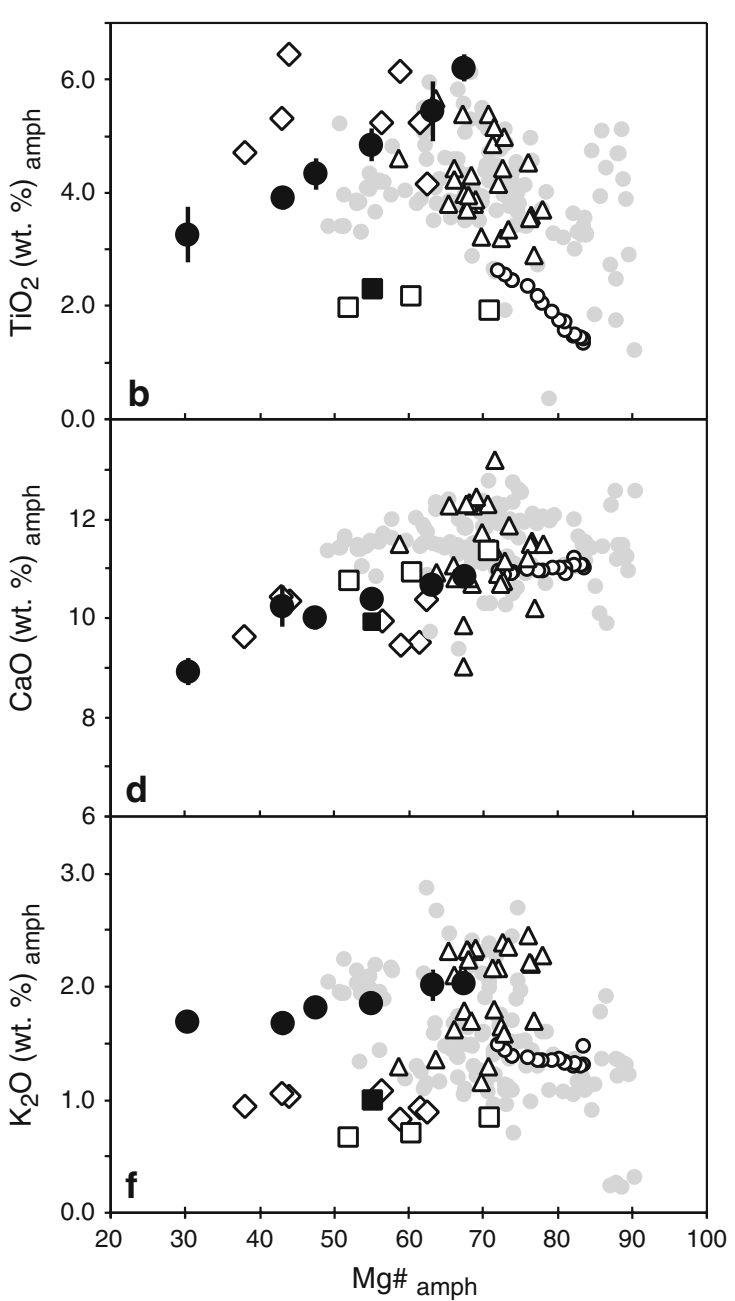

amphiboles from metasomatic veins (grey dots) and amphibole xenocrysts contained in alkaline basalts (open black triangles) are taken from Pilet et al. (2008) and references therein Open black circles correspond to compositional variations of amphiboles from the center (low Mg\#) to the margin (high $\mathrm{Mg \# )}$ of a lithospheric vein in contact with peridotite (Vaselli et al. 1995)

fractionation generates a decrease of the $\mathrm{MgO}$ content from 10.4 to 6.8 wt $\%$ while the fractionation of $20 \%$ of cpx only decreases the initial liquid $\mathrm{MgO}$ content to $9.6 \mathrm{wt} \%$. This relationship is not due to the difference of $\mathrm{Kd}_{\mathrm{Fe} / \mathrm{Mg}}^{\mathrm{min}}$ which is basically similar for both phases (Fig. 1), but is the consequence of the absolute amount of $\mathrm{MgO}$ incorporated in the mineral structures of olivine and cpx, respectively (43.2 vs. $13.8 \mathrm{wt} \%)$. The considerably higher modal amount of cpx relative to olivine in the high-pressure experiments compared to the Cantalian lavas and the lower pressure experimental melts of Nekvasil et al. (2004) where cpx appeared later on the liquidus $\left(\right.$ at $1,130^{\circ} \mathrm{C}$ ) results in significantly higher $\mathrm{TiO}_{2}, \mathrm{Na}_{2} \mathrm{O}, \mathrm{FeO} *$ contents at similar $\mathrm{MgO}$ contents. In the lower pressure experiments (Nekvasil et al. 2004) cpx was the dominant phase only below $1,100^{\circ} \mathrm{C}$ (Fig. 7). 

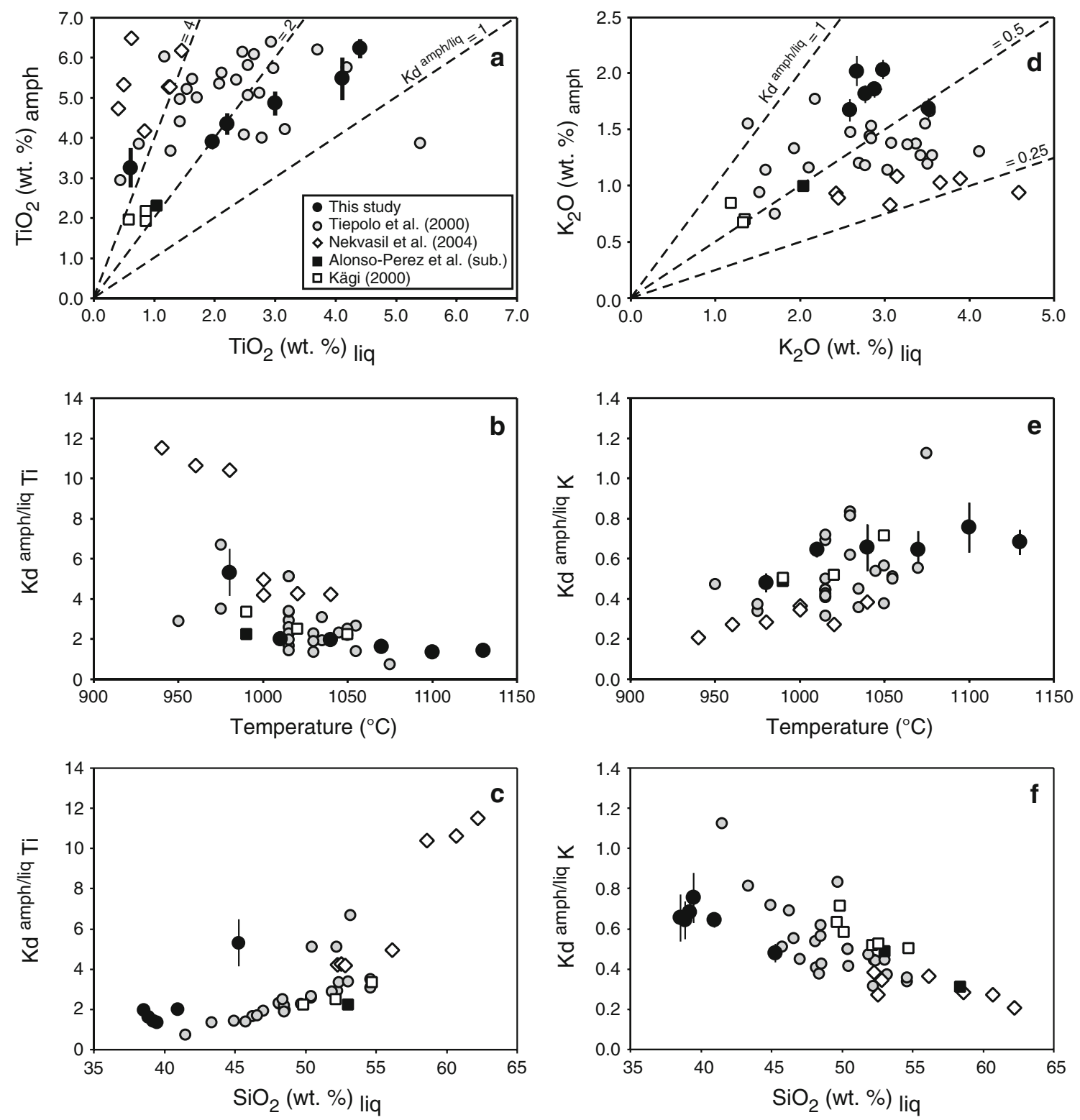

Fig. 5 Variation of amphibole compositions and $\mathrm{Kd}^{\mathrm{min} / \mathrm{liq}}$ for $\mathrm{TiO}_{2}$ and $\mathrm{K}_{2} \mathrm{O}$ versus liquid composition and experimental temperature. a $\mathrm{TiO}_{2}$ in amphibole versus $\mathrm{TiO}_{2}$ in liquid, b $\mathrm{Kd}_{\mathrm{TiO}}^{\mathrm{min} / \mathrm{liq}}$ versus experimental temperature, $\mathbf{c} \mathrm{Kd}_{\mathrm{TiO}_{2}}^{\mathrm{min} / \mathrm{liq}}$ versus $\mathrm{SiO}_{2}$ in the liquid, $\mathbf{d ~ K} \mathrm{K}_{2} \mathrm{O}$ in amphibole versus $\mathrm{K}_{2} \mathrm{O}$ in liquid, e $\mathrm{Kd}_{\mathrm{K}_{2} \mathrm{O}}^{\mathrm{min} / \mathrm{liq}}$ versus experimental temperature, and $\mathbf{f} \mathrm{Kd}_{\mathrm{K}_{2} \mathrm{O}}^{\mathrm{min} / \mathrm{liq}}$ in amphibole versus $\mathrm{SiO}_{2}$ in the liquid. Data points represent: FC experiments of an initial nephelinenormative basanite at $1.5 \mathrm{GPa}$ (this study, filled black circles with

Crystallization and fractionation of cpx also exert a strong control on the $\mathrm{CaO}$ content in residual liquids (Fig. 6e). However, the $\mathrm{CaO}-\mathrm{MgO}$ behavior in residual melts could not be used as a straightforward parameter to distinguish between low- or high-pressure fractionation products because plagioclase fractionation, which appears early in the differentiation process at lower pressure leads to decreasing $\mathrm{CaO}$ contents too and is most probably responsible for the

standard deviation $(1 \sigma))$; a hypersthene-normative hawaiite at $0.93 \mathrm{GPa}$ (open black diamonds; Nekvasil et al. 2004), and a hypersthene-normative picrobasalt at $1.5 \mathrm{GPa}$ (filled black squares; Alonso-Perez et al. 2009b) and 1.0 GPa (open black squares; Kägi 2000). Amphiboles from equilibrium crystallization experiments are taken from Tiepolo and (2000) at $1.5 \mathrm{GPa}$ (filled grey circles) and are shown for comparison

observed relationships in the Cantalian differentiation series (Wilson et al. 1995; Pilet et al. 2002).

The silica content of experimental liquids increases slightly but steadily at temperature below $1,130^{\circ} \mathrm{C}$ (Fig. 6a). This small $\mathrm{SiO}_{2}$ increase is controlled by a combination of spinel and ilmenite as well as amphibole fractionation. However, the difference in silica content between liquid and amphibole is too small to generate a 

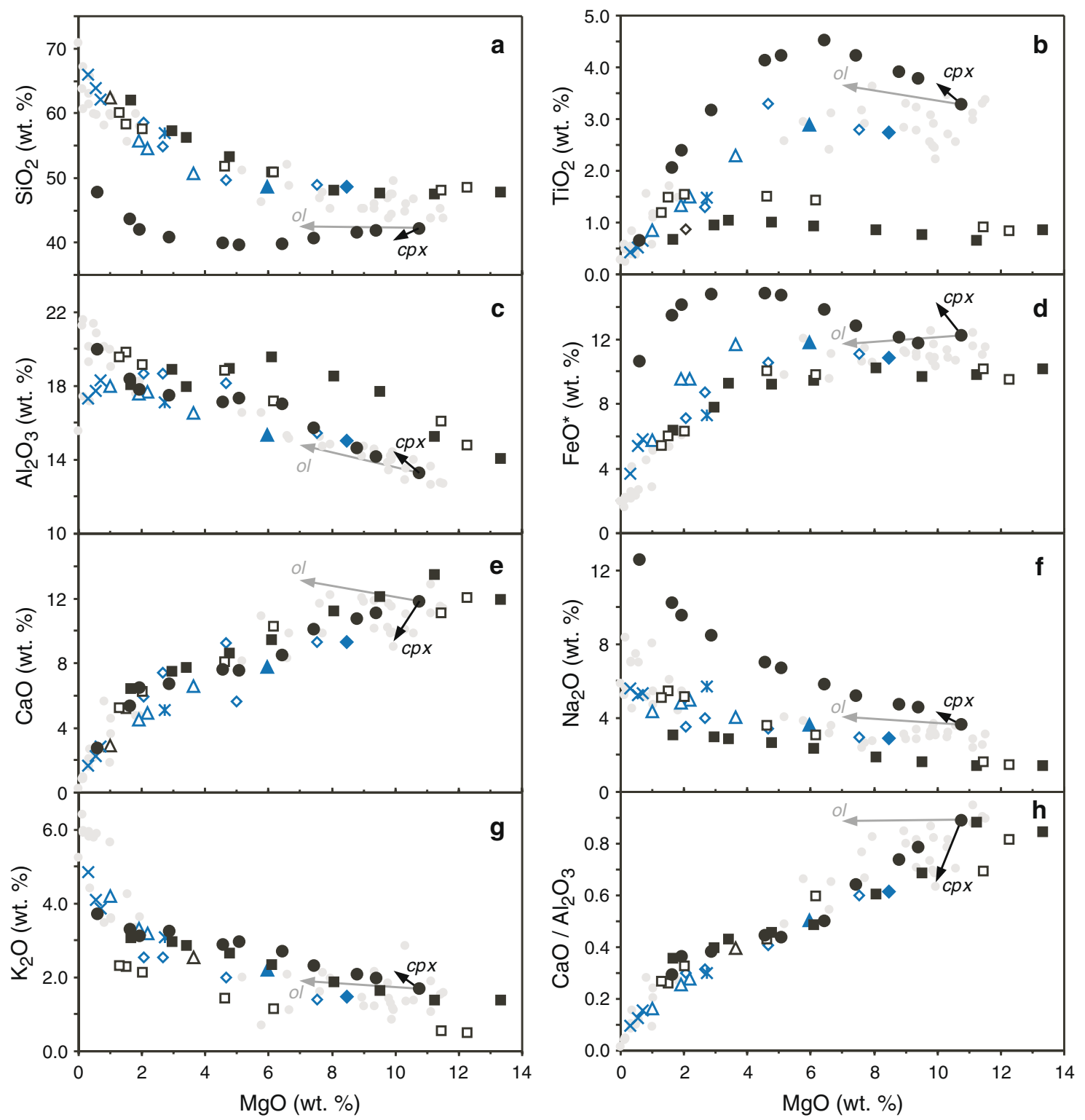

$$
\begin{aligned}
& \text { Cantal differentiation series } \\
& \text { FC basanite (this study) } \\
& \text { FC picrobasalt (1.5 GPa; Kagi, 2000) } \\
& \text { FC picrobasalt (1.5 GPa; Alonso-Perez et al., 2009b) }
\end{aligned}
$$

FC hawaiite (Nekvasil et al., 2004)

Start. Mat. A $\bullet$ Liq. A $\diamond$

Start. Mat. B $\triangle$ Liq. B $\Delta$

Start. Mat. $\mathrm{C} *$ Liq. $\mathrm{C} \times$
Fig. 6 Evolution of liquid compositions (on a volatile-free basis) in FC experiments from an initial nepheline-normative basanite at $1.5 \mathrm{GPa}$ (this study), a hypersthene-normative hawaiite at $0.93 \mathrm{GPa}$ (Nekvasil et al. 2004) and a hypersthene-normative picrobasalt at $1.5 \mathrm{GPa}$ (Alonso-Perez et al. 2009b) and $1.0 \mathrm{GPa}$ (Kägi 2000) as function of liquid $\mathrm{MgO}$ contents (in wt\%). a $\mathrm{SiO}_{2}, \mathbf{b ~ T i O} 2, \mathbf{c} \mathrm{Al}_{2} \mathrm{O}_{3}$,

significant $\mathrm{SiO}_{2}$ increase in the residual liquid at the onset of amphibole crystallization (for example in run \#6 at $1,130^{\circ} \mathrm{C}, \mathrm{SiO}_{2}$ in amphibole amounts to 39.3 vs. $39.2 \mathrm{wt} \%$ in the coexisting glass; Table 2) and, hence, the crystallization of $\mathrm{Fe}-\mathrm{Ti}$ oxides is crucial to initiate an increase in the silica content. Nevertheless, amphibole fractionation d $\mathrm{FeO} *$, e $\mathrm{CaO}, \mathbf{f ~} \mathrm{Na}_{2} \mathrm{O}, \mathbf{g ~ K} \mathrm{K}_{2} \mathrm{O}$, and $\mathbf{h} \mathrm{CaO} / \mathrm{Al}_{2} \mathrm{O}_{3}$. The grey and black arrows indicate the effect of $10 \%$ olivine and $20 \%$ cpx fractionation from the initial basanite \#31, respectively. This figure highlights the pressure influence on differentiation trends of alkaline magmas (lowpressure Cantal Massif vs. high-pressure FC basanite, this study)

could result in a significant $\mathrm{SiO}_{2}$ increase in the residual liquid provided that the starting liquid composition is more silica-rich (e.g., for the case of run \#11 of this study or for the evolution of an initial hy-normative starting composition (Nekvasil et al. 2004; Fig. 6a). Figure 6 reveals that the behavior of $\mathrm{Al}_{2} \mathrm{O}_{3}, \mathrm{CaO}, \mathrm{MgO}, \mathrm{Na}_{2} \mathrm{O}$ and $\mathrm{K}_{2} \mathrm{O}$ at 

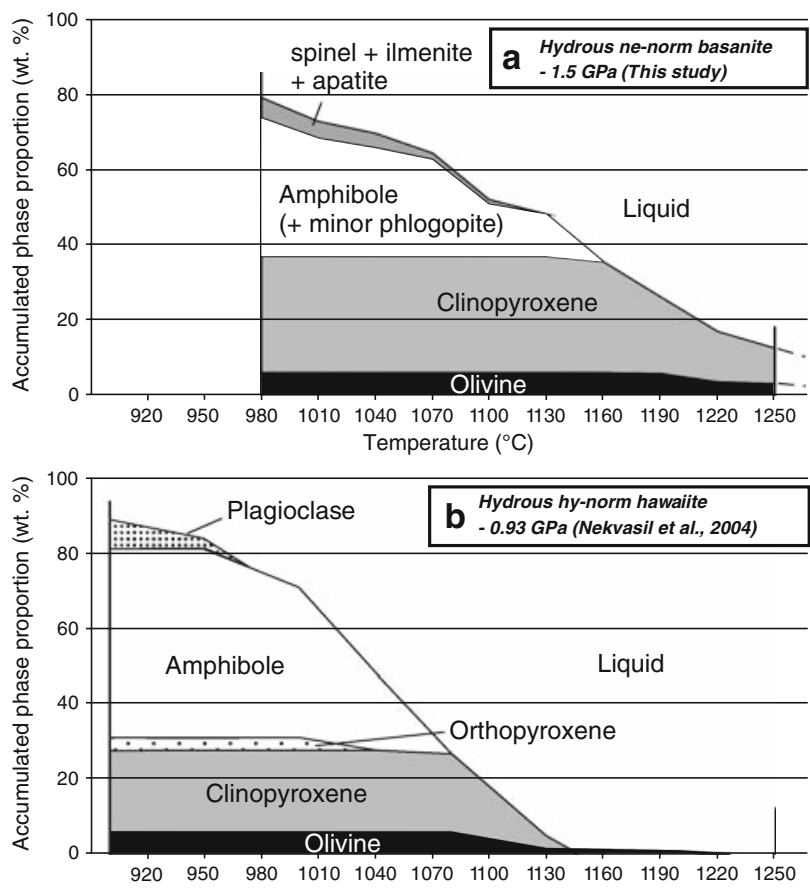

Temperature $\left({ }^{\circ} \mathrm{C}\right)$
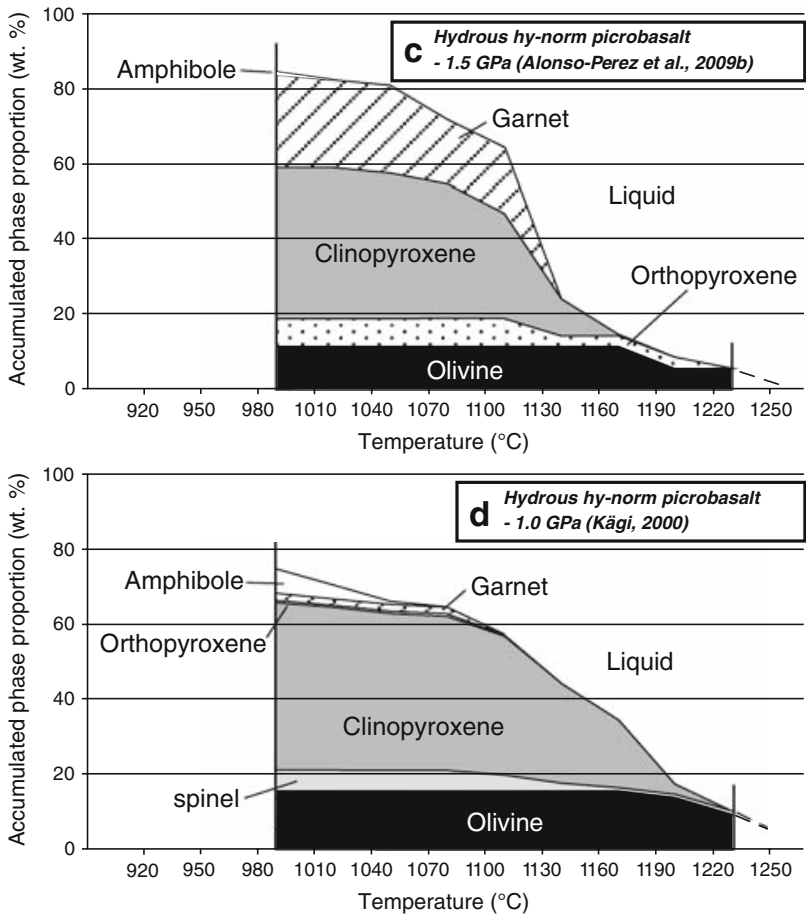

Fig. 7 Accumulated solid phases during fractional crystallization of an initial nepheline-normative basanite at $1.5 \mathrm{GPa}$ (a) (this study); hypersthene-normative hawaiite at $0.93 \mathrm{GPa}$ (b) Nekvasil et al. (2004); hypersthene-normative picrobasalt at $1.5 \mathrm{GPa}$ (c) AlonsoPerez et al. 2009b and 1.0 GPa (d) Kägi (2000)

temperature below $1,130^{\circ} \mathrm{C}$ is predominantly controlled by the fractionation of amphibole. Only the behavior of $\mathrm{FeO}^{*}$ and $\mathrm{TiO}_{2}$ reflect the additional fractionation of $\mathrm{Fe}-\mathrm{Ti}$ oxides phases; the $\mathrm{P}_{2} \mathrm{O}_{5}$ content (Fig. 2i) is characterized by an increase of the $\mathrm{P}_{2} \mathrm{O}_{5}$ content until $1,040^{\circ} \mathrm{C}$ (run \#9) when apatite starts to crystallize resulting in a decrease of $\mathrm{P}_{2} \mathrm{O}_{5}$ at lower temperatures.

A fundamental difference between the liquid line of descent of (hydrous) basanite at high pressure (this study) and other experiments either at lower pressure on dry tholeiite basalt (Villiger et al. 2004) or hydrous hy-normative hawaiite (Nekvasil et al. 2004) is the absence of feldspar crystallization (Fig. 7) that is consistent with highpressure phase equilibrium of hydrous picrobasalt at 1.5 (Alonso-Perez et al. 2009b) and 1.0 GPa (Kägi 2000). The picrobasalt experiments at $1.5 \mathrm{GPa}$, however, were characterized by abundant garnet crystallization instead. The absence of feldspar (plagioclase) crystallization causes the different $\mathrm{Al}_{2} \mathrm{O}_{3}$ behavior observed at low temperature in the present study (a continuous increase) relative to the hydrous $h y$-normative experiments at $0.93 \mathrm{GPa}$ of Nekvasil et al. (2004) where a strong $\mathrm{Al}_{2} \mathrm{O}_{3}$ decrease is observed with the appearance of plagioclase (experimental liquid $\mathrm{C}$ in Fig. 6c). The absence of feldspar crystallization in the present experiments results from a combination of pressure that was too high to promote feldspar crystallization (Green and Ringwood 1968) and from the high $\mathrm{H}_{2} \mathrm{O}$ content, which decreases the feldspar stability relative that of the $\mathrm{Fe}-\mathrm{Mg}$ phases (Muntener et al. 2001; Sisson and Grove 1993). The low $\mathrm{Al}_{2} \mathrm{O}_{3}$ content and silica undersaturated nature of the basanitic starting material (Fig. 6c) is most probably responsible for the absence of garnet in our experiments compared to the 1.5-GPa hydrous picrobasalt experiments of Alonso-Perez et al. (2009b).

Comparison between high-pressure cumulates produced by $n e$-normative and $h y$-normative liquids

This experimental study reveals that fractional crystallization (FC) of a hydrous ne-normative liquid at $1.5 \mathrm{GPa}$ produces anhydrous to hydrous cumulates in a continuum process (Fig. 3); i.e., clinopyroxenite with minor olivine $(\mathrm{cpx} / \mathrm{ol}>4)$ to hornblendites with accessory phases ( \pm apatite \pm ilmenite). The present experiments show that anhydrous cumulates represent $35 \% \quad(29 \% \quad \mathrm{cpx}+6 \%$ olivine) of the initial liquid mass, hydrous cumulates $43 \%$ (36\% amphibole plus minor cpx, phlogopite and accessories) with $21 \%$ of residual liquid remaining at $980^{\circ} \mathrm{C}$ (Fig. 7). These results strongly suggest that the volume of hydrous metasomatic veins produced by the percolation and differentiation of hydrous basanitic liquid at mantle depth is significant. The sequence of anhydrous-hydrous cumulates is in agreement with models proposed for the formation of metasomatic veins within the lithospheric mantle (Harte et al. 1993; Nielson and Noller 1987; Wilshire 1987). However, a similar sequence is also observed for the differentiation of $h y$-normative liquid at 
similar pressure as depicted in Fig. 7 that compares cumulates formed by the evolution of ne-normative basanite with the evolution of hy-normative basic hawaiite and picrobasalt for pressure between 0.93 and $1.5 \mathrm{GPa}$. All series of fractional crystallization experiments reported in Fig. 7 result the formation of anhydrous cumulates [olivine-cpx \pm orthopyroxene (opx)] at high temperature followed by hydrous cumulates (amphibole \pm garnet \pm plagioclase) at lower temperature. However, there are significant differences in the relative proportions of anhydrous versus hydrous cumulates produced from the different initial liquids. The evolution of the picrobasalt (Alonso-Perez et al. 2009b; Kägi 2000) generates significantly more ultramafic anhydrous cumulates $(\sim 60 \%)$ relative to hawaiite (Nekvasil et al. 2004) and basanite $(\sim 30-40 \%)$. This difference is most probably related to the degree of "primitivity" of the different starting material testified by the amount of normative olivine they contain. A comparison of the $\mathrm{Mg \#}$ of the three distinct starting materials reveals that basanite and hawaiite are characterized by significantly lower Mg\# (61.1 and 58.2 for basanite and hawaiite, respectively), than the picrobasalt $(\mathrm{Mg \#}=73)$. Picrobasalt is in equilibrium with mantle lithology and mineral compositions (olivine + opx + cpx + garnet) at 2.8 GPa (Ulmer 1989) and corresponds, therefore, to a primary liquid [liquid with $\mathrm{Mg} \#$ of 73 is equilibrium with mantle Fo $_{90}$ olivine (Roeder and Emslie 1970)]. The basanite and hawaiite are not primary but parental (evolved) magma composition. This observation suggests that more primitive $n e$-normative or $h y$-normative liquids than the basanite or hawaiite used as initial starting materials in this study or in Nekvasil et al.'s (2004) study would also generate larger proportions of anhydrous cumulates. However, the proportion of anhydrous versus hydrous cumulates is additionally related to the temperature where amphibole starts to crystallize. Amphibole appears in the basanite $\mathrm{FC}$ experiments at $1,130^{\circ} \mathrm{C}$ while amphibole is first observed in runs at $1,040^{\circ} \mathrm{C}$ in the hawaiite experiments and at 990 and $1,050^{\circ} \mathrm{C}$ in the picrobasalt experiments at 1.5 and $1 \mathrm{GPa}$, respectively (Fig. 7). Hawaiite and basanite FC experiments indicate that amphibole becomes the dominant crystallizing phase once it reaches its stability field; this is also true for the picrobasalt experiments at 1,020 and $990^{\circ} \mathrm{C}$ at $1.0 \mathrm{GPa}$ (Kägi 2000). This point is further supported by equilibrium crystallization experiments on an andesitic starting material representing a liquid produced by fractional crystallization of a picrobasalt at $1,020^{\circ} \mathrm{C}$ and $1 \mathrm{GPa}$ (Kägi 2000). This study reveals that amphibole, coexisting with minor garnet and plagioclase are the principal phases produced in the temperature range $800-950^{\circ} \mathrm{C}$ at 0.8 and $1.2 \mathrm{GPa}$ (AlonsoPerez et al. 2009a; Muntener and Ulmer 2006). According to Sisson and Grove (1993) and Gilbert et al. (1982), amphibole stability at a given pressure is bulk composition dependant; in particular the $\mathrm{Fe}-\mathrm{Mg}$ ratio and the alkali content of the melt (system) exert strong control. The different FC experiments presented in Fig. 7 support the latter conclusion: liquids evolving from an initial basanitic composition characterized by early amphibole appearance are significantly more enriched in alkalis than liquids generated from the hawaiite or picrobasalt (Fig. 6). However, we cannot a priori exclude that other parameters such $\mathrm{H}_{2} \mathrm{O}$ content of the liquid and/or $\mathrm{fO}_{2}$ could additionally influence the amphibole stability. Since the experimental condition varied considerably between the different fractional crystallization experimental studies (e.g., experiments conducted in graphite-Pt capsule for the basanite study at relatively low $\mathrm{fO}_{2}$ as opposed to double capsule AuPd-Pt experiments at higher $\mathrm{fO}_{2}$ for the picrobasalt studies), we are not able to evaluate the potential contributions of bulk composition versus other parameters in a quantitative way.

An additional, obvious difference between various FC studies is the presence of opx in the hawaiite and picrobasalt experiments (Fig. 7). Theoretical (O'Hara 1968) and experimental studies (Shaw 1999; Shaw et al. 1998; Lundstrom 2000; Pilet et al. 2008) have demonstrated that opx is not stable in ne-normative liquids. Therefore, the absence of opx in cumulates produced along the basanite liquid line of descent at $1.5 \mathrm{GPa}$ is predictable and consistent. The fractionation of minor opx in addition to olivine during the FC process does not significantly affect the composition of residual liquid except for $\mathrm{SiO}_{2}$ that could be decreased by the fractionation of opx. Nevertheless, the presence or absence of opx in metasomatic veins could potentially be used as an indicator for the nature of the metasomatic agent (i.e., hy- vs. ne-normative liquids).

\section{Amphibole-liquid relationship}

Amphibole is considered a major metasomatic phase and is observed in lithospheric veins, mantle xenoliths and as xenocrysts in alkaline basalts (Dawson and Smith 1982). Therefore, the understanding of the parameters that control amphibole composition is a prerequisite to constrain the processes responsible for hydrous metasomatic vein formation. Figure 4 compares the composition of amphiboles, which crystallized in FC studies from initial basanitic, hawaiitic and picrobasaltic liquids, with the composition of amphibole from metasomatic veins and from xenocryts observed in alkaline basalts. The range of $\mathrm{SiO}_{2}, \mathrm{Al}_{2} \mathrm{O}_{3}$, $\mathrm{CaO}$ and $\mathrm{Na}_{2} \mathrm{O}$ contents observed in the amphiboles from the different FC experiments partly overlaps showing a moderate decrease of $\mathrm{SiO}_{2}$ and $\mathrm{CaO}$ with the decreasing

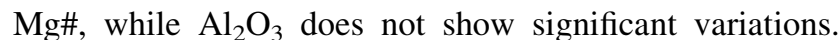
Principal differences between the different series of FC 
experiments are observed for $\mathrm{K}_{2} \mathrm{O}$ and $\mathrm{TiO}_{2}$ : amphiboles from basanite and hawaiite $\mathrm{FC}$ experiments are significantly more enriched in $\mathrm{TiO}_{2}$ than amphibole formed in the picrobasalt $\mathrm{FC}$ experiments. This feature is, in part, related to the $\mathrm{TiO}_{2}$ content of the liquid from which these amphiboles crystallized. However, Fig. 5a clearly indicates that the $\mathrm{Kd}_{\mathrm{TiO}_{2}}^{\mathrm{amph} / \mathrm{liq}}$ increase with decreasing $\mathrm{TiO}_{2}$ content in the liquid. Figure $5 \mathrm{~b}$ illustrates the evolution of $\mathrm{Kd}^{\mathrm{amph} / \mathrm{iq}}$ for $\mathrm{TiO}_{2}$ as a function of temperature: a negative correlation between $\mathrm{Kd}_{\mathrm{TiO}_{2}}^{\mathrm{amph} / \mathrm{liq}}$ and the experimental temperature is observed in all FC experiments as well as in equilibrium experiments conducted at $1.4 \mathrm{GPa}$ on various starting compositions by Tiepolo et al. (2000) (Fig. 5b). The $\mathrm{Kd}_{\mathrm{TiO}_{2}}^{\mathrm{amph} / \mathrm{liq}}$ can attain extremely high values $(>10)$ as observed in some experiments performed below $980^{\circ} \mathrm{C}$ in the FC hawaiite experiments (Nekvasil et al. 2004). The increase in $\mathrm{Kd}_{\mathrm{TiO}_{2}}^{\mathrm{amph} / \mathrm{liq}}$ with decreasing temperature in basically observed in all fractional crystallization and equilibrium crystallization experiments (Tiepolo and 2000; Ulmer, unpublished data on a primary basanite) and is in line with many similar studies, for example on cpx-liquid partitioning (e.g., Ray et al. 1983). This effect is interpreted to reflect decreasing compatibility of $\mathrm{Ti}$ in residual liquids depleted in network modifying cations $(\mathrm{Mg}, \mathrm{Fe}, \mathrm{Ca})$. Figure $5 \mathrm{c}$ clearly reveals the positive correlation between $\mathrm{Kd}_{\mathrm{TiO}_{2}}^{\text {amph/liq }}$ and $\mathrm{SiO}_{2}$ content of the liquid supporting the effect of the degree of polymerization of the liquid on the $\mathrm{Kd}_{\mathrm{TiO}_{2}}^{\text {amph/liq }}$ previously pointed out by Tiepolo et al. (2000) for $\mathrm{Kd}_{\mathrm{REE}}^{\text {amph/liq }}$ (the $\mathrm{SiO}_{2}$ content of the liquids presented in Fig. $5 \mathrm{c}, \mathrm{f}$ is considered as a proxy for the degree of polymerization of the liquid as increasing $\mathrm{SiO}_{2}$ is generally correlated with decreasing amounts of network modifying cations such as $\mathrm{Mg}, \mathrm{Fe}$ and $\mathrm{Ca}$ ). However, considering that temperature and degree of differentiation of the liquid are directly correlated, a quantitative distinction between the relative contribution of temperature and liquid composition (polymerization) on $\mathrm{Kd}_{\mathrm{TiO}}^{\mathrm{amph} / \mathrm{liq}}$ is not warranted.

Figure $4 \mathrm{f}$ indicates that the $\mathrm{K}_{2} \mathrm{O}$ contents of amphiboles in any specific series of FC experiments display a moderate, but systematic increase of $\mathrm{K}_{2} \mathrm{O}$ with increasing $\mathrm{Mg \#}$ and/or temperature. Similar to $\mathrm{TiO}_{2}, \mathrm{Kd}_{\mathrm{K}_{2} \mathrm{O}}^{\text {amph/liq }}$ depends on temperature and degree of polymerization of the liquid (Fig. 5e, f). However, the effect is opposite to that observed for $\mathrm{TiO}_{2}$ or other incompatible high field strength elements or Th, U and REE (Tiepolo and 2000): $\mathrm{Kd}_{\mathrm{K}_{2} \mathrm{O}}^{\mathrm{amph} / \mathrm{liq}}$ decreases with decreasing temperature and with increasing concentrations of network modifying cations in the liquid (Fig. 5e, f). Moreover, $\mathrm{K}_{2} \mathrm{O}$ contents of amphibole exhibit a strong dependence on experimental pressure. Experiments performed at 1.4-1.5 GPa (this study; Tiepolo and 2000) contain amphiboles with $\mathrm{K}_{2} \mathrm{O}$ contents between $\sim 1$ and $2 \mathrm{wt} \%$, while lower pressure experiments $(\leq 1 \mathrm{GPa})$ produced amphiboles with $\mathrm{K}_{2} \mathrm{O}$ contents below $1.1 \mathrm{wt} \%$
(Fig. 5d). Inspection of $\mathrm{Na}-\mathrm{K}-\mathrm{Ca}$ relationships as a function of temperature in amphiboles from this study (Fig. 8) reveals (1) an increase of $\mathrm{K}_{2} \mathrm{O}$ accompanied by a decrease of $\mathrm{Na}_{2} \mathrm{O}$ with increasing temperature, i.e., most probably an isostructural exchange of $\mathrm{K}$ for $\mathrm{Na}$ on the $\mathrm{A}$ site of amphibole with increasing temperature. This is most probably related to the fact the $\mathrm{K}$ has a larger ionic radius then $\mathrm{Na}$ and, hence, increasing temperature at constant pressure results in an expansion of the amphibole lattice thereby promoting increasing substitution of $\mathrm{K}$ for $\mathrm{Na}$ on this particular site. This is clearly supported by the decreasing $\mathrm{Na}_{2} \mathrm{O} / \mathrm{K}_{2} \mathrm{O}$ ratio of amphiboles with increasing temperature. (2) However, this substitution is not exclusively responsible for increasing $\mathrm{Na}_{2} \mathrm{O}$ with decreasing temperature: The increase in Na clearly overcompensates for decreasing $\mathrm{K}$; using cations per formula units, based on 13 cations $+\mathrm{Ca}+\mathrm{Na}+\mathrm{K}$ and 24 charges including 2 $\mathrm{OH}, \mathrm{K}$ decreases from 0.386 to 0.327 , but $\mathrm{Na}$ increases from 0.748 to 1.101 , i.e., Na increases 5 times more than $\mathrm{K}$ decreases. Concomitantly, $\mathrm{Ca}$ decreases from 1.73 to 1.47 p.f.u. indicating that $\mathrm{Na}$ strongly increases on the M4 site of the amphibole with decreasing temperature at constant pressure; the strongest decrease in $\mathrm{Ca}$ and concomitant increase in Na on the M4 site is observed for the last fractionation step between 1,010 and $980^{\circ} \mathrm{C}$. This $\mathrm{Na}$ substitution is most probably favored by both decreasing temperature and increasing $\mathrm{Fe}$ component in the amphibole leading to a combined glaucophane $\left(\mathrm{Na}^{[\mathrm{M} 4]} \mathrm{Al}^{[6]}=\right.$ $\left.\mathrm{Ca}^{[\mathrm{M} 4]} \mathrm{Mg}^{[6]}\right)$ and riebeckite $\left(\left(\mathrm{Na}^{[\mathrm{M} 4]} \mathrm{Fe}^{3+[6]}=\mathrm{Ca}^{[\mathrm{M} 4]}(\mathrm{Mg}\right.\right.$, $\left.\mathrm{Fe}^{2+}\right)^{[6]}$ ) exchange. This is further supported by the fact that recalculated ferric iron contents of the experimental amphibole increase from 0 to 0.23 p.f.u. with decreasing temperature. In summary, $\mathrm{K}-\mathrm{Na}-\mathrm{Ca}$ compositions and partitioning of amphibole in the present experimental series clearly points towards a dominantly crystal structural and pressure control that overrules changes in liquid compositions unlike Ti where the liquid composition and temperature exert the dominant control.

Implication of FC experiments for metasomatic veins formation

As outlined in the "Introduction", most authors agree that the formation of anhydrous and hydrous metasomatic veins and the cryptic metasomatism in the surrounding lithospheric mantle are linked in a continuous process (Harte et al. 1993; Nielson and Noller 1987; Nielson and Wilshire 1993; Wilshire 1987). However, the origin of the melts that generate such metasomatism remains unconstrained. The most widely cited mechanism involves derivation from low-degree partial melting of $\mathrm{H}_{2} \mathrm{O}-\mathrm{CO}_{2}$-bearing garnet peridotite (McKenzie 1989; McKenzie and O'Nions 1995; Nielson and Noller 1987; Niu and O'Hara 2003; Wilshire 
Fig. 8 Variation of a $\mathrm{K}_{2} \mathrm{O}$, b $\mathrm{Na}_{2} \mathrm{O}$, c $\mathrm{CaO}$ (in wt\%) and $\mathbf{d}$ the $\mathrm{Na}_{2} \mathrm{O} / \mathrm{K}_{2} \mathrm{O}$ ratio of amphiboles produced by fractional crystallization of an initial basanite as a function of temperature
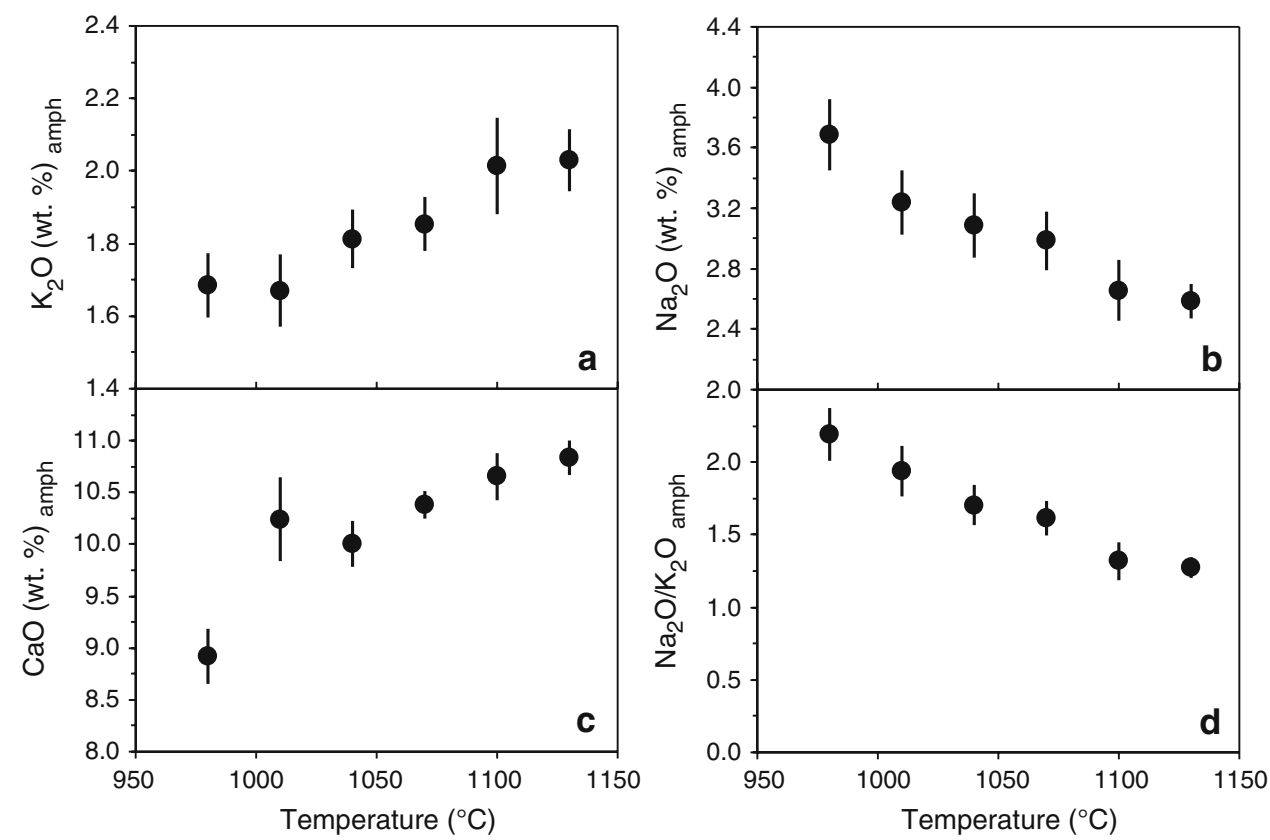

1987). In this section, we compare the compositions of metasomatic veins with cumulates formed by in FC experiments in order to put constraints on the origin of the initial metasomatic melts.

Clinopyroxene is the dominant mineral in anhydrous metasomatic veins observed in the French Pyrenees and other peridotitic massifs (Bodinier et al. 1987a; Conquere 1977). This mineral is associated with various proportion of olivine \pm opx \pm garnet. While the association cpx + olivine is observed in the ne-normative and the hy-normative FC experimental series (Fig. 7), opx does not crystallize in the ne-normative basanite FC experiments. As indicated previously, theoretical (O'Hara 1968) and experimental studies (Jakobsson and Holloway 1986; Shaw 1999; Shaw et al. 1998; Lundstrom 2000; Pilet et al. 2008) have demonstrated that opx is not stable in ne-normative liquids at low to moderate $\mathrm{CO}_{2}$ contents. Opx could be formed by the peritectic reaction between the percolating metasomatic liquid and the surrounding peridotite olivine + liquid $\mathrm{A} \rightarrow$ opx + liquid $\mathrm{B}$ (with liquid $\mathrm{B}$ being lower in silica than liquid A; Sobolev et al. 2005; Yaxley and Green 1998). However, this reaction only occurs if liquid A is silica saturated (O'Hara 1968; Yaxley and Green 1998). If the liquid is silica undersaturated, the reaction is reversed and opx reacts with the silica undersaturated liquid to generate a liquid enriched in silica + olivine (Shaw 1999; Shaw et al. 1998; Lundstrom 2000; Pilet et al. 2008) at lithospheric pressures (i.e., $<20$ kbar). Therefore, the association of opx with cpx (or amphibole) in metasomatic veins suggests that the liquids that produced these cumulates could be silica-saturated liquids (i.e., hy-normative such as some transitional alkaline olivine basalts or tholeiitic basalts) rather then ne-normative liquids such as nephelinite or basanite. The observation of opx in association with cpx and/or amph in websterite \pm amph, amphibole-pyroxenite and garnet amphibole-pyroxenite from French Pyrenees (Bodinier et al. 1987a, b; Conquere 1971, 1977) as well as in xenoliths carried by alkaline lavas from, for example, the Iki-island, Japan (Aoki 1970), Dish Hill, USA (Wilshire et al. 1980), Never basalts, Australia (Irving 1974) suggest that these lithologies are potentially produced by a silicasaturated liquid rather then by undersaturated ones. These observations question the interpretation of these metasomatic lithologies as representing products of percolation and differentiation of hydrous undersaturated liquids. However, the ne-normative experiments reported here were performed by starting from a highly $n e$-normative basanite (ne $+L c=22.7$ mole\% in the CIPW norm on a volatilefree basis) were conducted exclusively at $1.5 \mathrm{GPa}$ and with volatile content dominated by $\mathrm{H}_{2} \mathrm{O} \quad\left[\mathrm{H}_{2} \mathrm{O}: \mathrm{CO}_{2}\right.$ (in $\mathrm{wt} \%)>2$ in all experiments]. Therefore, we advocate that more experiments are indeed required to clarify, first, if metasomatic veins containing opx could be produced by slightly ne-normative liquids such as alkali olivine basalt as produced from low degree of partial melting of peridotite (Baker and Stolper 1994; Hirose and Kushiro 1993; Walter 1998) and, second, to explore the role of $\mathrm{CO}_{2}$ and pressure on opx stability in $n e$-normative liquids. Nevertheless, it is most likely that metasomatic veins containing opx are not produced from the differentiation of basanitic or nephelinitic melts.

The presence of garnet is observed only in the picrobasalt FC experimental studies (Fig. 7). This suggests that 
anhydrous vein assemblages containing garnet are only produced by $h y$-normative hydrous liquids at pressures equal or lower than $1.5 \mathrm{GPa}$. However, equilibrium experiments on a primary basanite composition conducted at pressures between 0.5 and $3 \mathrm{GPa}$ suggest that garnet could crystallize in association with cpx at higher pressures (2.0-3.0 GPa, Ulmer unpublished data). Therefore, the presence or absence of garnet could not be used to identify unequivocally the liquid composition that generated garnet-bearing hydrous and anhydrous metasomatic veins.

Figure 4 compares the composition of amphiboles crystallized in FC experiments from basanite, hawaiite and picrobasalt initial compositions with a compilation of amphibole compositions from lithospheric veins and amphiboles observed as xenocrysts in alkaline lavas. These xenocrysts are interpreted to originate from disaggregated metasomatic veins (Basu 1978; Dawson and Smith 1982; Irving and Frey 1984; Kramers et al. 1983; Menzies and Murthy 1980). The range of amphibole compositions crystallizing in FC experiments overlap with the compositional range observed in amphiboles from metasomatic veins for $\mathrm{SiO}_{2}, \mathrm{Al}_{2} \mathrm{O}_{3}, \mathrm{TiO}_{2}, \mathrm{CaO}, \mathrm{Na}_{2} \mathrm{O}$ and $\mathrm{K}_{2} \mathrm{O}$ (Fig. 4). Nevertheless, the range of $\mathrm{Mg \#}$ observed in amphiboles obtained from FC experiments and amphiboles originating from metasomatic veins are slightly distinct (Fig. 4). Experimentally produced amphiboles display an $\mathrm{Mg \#}$ range from 70 to 30 while the compositions of amphiboles observed in metasomatic veins vary from 90 to 50 . Detailed studies of metasomatic veins revealed that $\mathrm{Mg} \#$ in amphiboles increase from the center to the contact of the vein with the surrounding mantle. This is illustrated in Fig. 4 by the profile published by Vaselli et al. (1995) (open circles). The increase of $\mathrm{Mg \#}$ is interpreted as a subsolidus re-equilibration of deposited cumulate phases with the surrounding mantle (Bodinier et al. 1987b; Irving 1980; Vaselli et al. 1995). Consequently, amphiboles with $\mathrm{Mg} \#$ exceeding 80 could easily be interpreted as the result of reequilibration with surrounding mantle. Nevertheless, it seems likely that some if not the majority of amphiboles with $\mathrm{Mg \#}$ between 70 and 80 reflect their primary Mg\#. This suggests that amphiboles from metasomatic veins have crystallized from a melt characterized by a higher $\mathrm{Mg} \#$ than the liquids that formed the amphiboles in the experiments reported in Fig. 4. Two hypotheses could explain this discrepancy in Mg\#: (1) the metasomatic melts that generate the veins could conserve high $\mathrm{Mg \#}$ by constantly reacting with the surrounding lithospheric mantle; (2) the anhydrous assemblage that fractionates at high temperature does not involve significant olivine, which allowed the liquid to remain rather $\mathrm{MgO}$-rich until relatively low temperatures were attained $\left(\sim 1,100-1,150^{\circ} \mathrm{C}\right.$; temperature where amphibole starts to crystallized). Both explanations seem possible. Harte et al. (1993) suggested

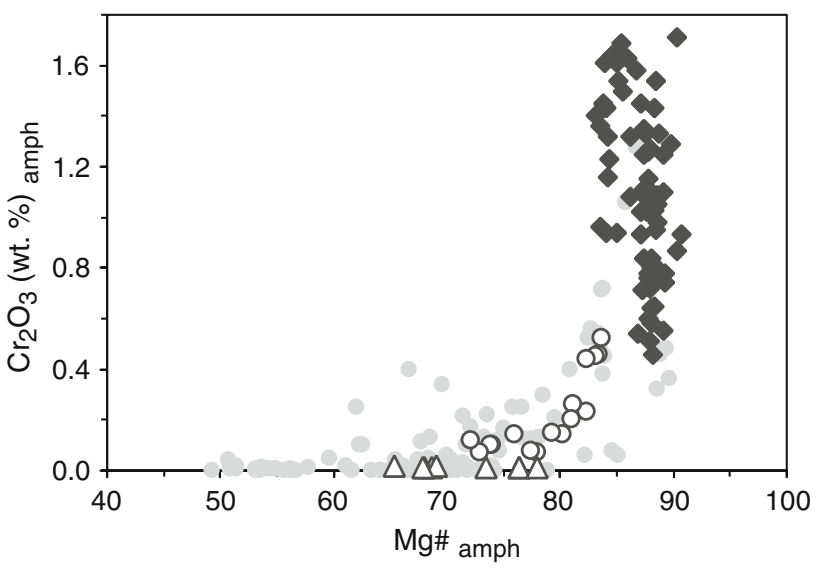

Fig. $9 \mathrm{Cr}_{2} \mathrm{O}_{3}$ (wt\%) versus $\mathrm{Mg} \#$ diagram of amphiboles from oceanic and continental lithospheric metasomatic veins (filled grey circles), xenocrysts in alkaline basalts (open triangles) and metasomatized peridotites (black diamonds). Open black circles correspond to compositional variations of amphiboles from the center (low Mg\#) to the margin (high $\mathrm{Mg \# )}$ of a lithospheric vein in contact with peridotite (Vaselli et al. 1995)

that the metasomatic melts maintain equilibrium with host rock phases (i.e., peridotite), at least for rapidly diffusing species such as $\mathrm{Fe}-\mathrm{Mg}$, during so-called percolative fractional crystallization processes that are thought to be responsible for metasomatic vein formation. However, there is also a population of amphiboles and cpx from metasomatic veins that show low $\mathrm{Mg} \#$ compositions (below Mg\# 60; Fig. 4), which suggests that this equilibrium is not maintained under all possible circumstances. In addition, amphiboles from metasomatic veins and xenocrysts are (1) characterized by $\mathrm{Cr}_{2} \mathrm{O}_{3}$ contents that are significantly lower than in amphiboles in the peridotite matrix and, (2) they show a clear positive (exponential) correlation between $\mathrm{Cr}_{2} \mathrm{O}_{3}$ content and $\mathrm{Mg \#}$ (Fig. 9). This hyperbolic decrease is consistent with a differentiation process involving cpx \pm spinel fractionation and implies absence of $\mathrm{Cr}$ "buffering" by the surrounding peridotite (i.e., spinel, pyroxene or garnet). High-pressure equilibrium crystallization experiments on a hydrous, $\mathrm{CO}_{2}$-bearing basanitic liquid (Ulmer, unpublished data) reveals that with increasing pressure, the olivine stability field retracts to a small temperature interval close to the liquidus immediately followed by $\mathrm{cpx}+$ garnet crystallization above $1.5 \mathrm{GPa}$ and completely vanishes above $2.5 \mathrm{GPa}$. This suggest that the differentiation of "primitive" basaltoid liquids $(\mathrm{Mg} \# \sim 72)$ at high pressure $(>1.5 \mathrm{GPa})$ is distinct from the moderate pressure trend $(<1.5 \mathrm{GPa})$ where olivine is a dominant phase in the sub-liquidus region. High-pressure garnet $+\mathrm{cpx}$ fractionation that is only preceded by very minor olivine extraction could maintain a relatively high $\mathrm{MgO}$ content and $\mathrm{Mg} \#$ in the liquid phase until relatively low temperature is reached as 
garnet does not strongly fractionate $\mathrm{Fe}$ from $\mathrm{Mg}$ unlike olivine and cpx and allowed amphibole to crystallize with $\mathrm{Mg \#}$ higher than in the experiments at $1.5-0.93 \mathrm{GPa}$

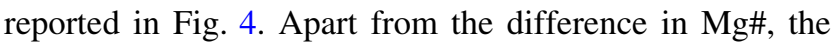
compositions of amphiboles from metasomatic veins are similar to amphiboles that crystallized in the FC experiments. This supports the possible interpretation of metasomatic veins as cumulates that segregated during a differentiation process of primary to derivative liquids in the mantle lithosphere.

The distinct $\mathrm{TiO}_{2}$ and $\mathrm{K}_{2} \mathrm{O}$ contents observed in amphibole from FC experiments from basanite, hawaiite and picrobasalt could be principally used to constrain the composition of melts responsible for the formation of metasomatic hydrous veins. The $\mathrm{K}_{2} \mathrm{O}$ content in amphibole is inferred to be a function of pressure and temperature rather than the composition of the liquid and, thus, is potentially independent of the nature of the system, i.e., silica undersaturated or saturated (Figs. 4f, 5d-f). Therefore, the high $\mathrm{K}_{2} \mathrm{O}$ content observed in some high $\mathrm{Mg \#}$ amphiboles from metasomatic veins (2-2.5 wt\%; Fig. 4f) suggests that the crystallization pressure of these amphiboles is comparable to the conditions of the basanite FC experiments $(1.5 \mathrm{GPa})$. A lower pressure limit for amphibole crystallization $(\sim 1 \mathrm{GPa})$ could be estimated from the FC experiments conducted on hy-normative hawaiite resulting in $\mathrm{K}_{2} \mathrm{O}$ amphibole contents that are lower than commonly observed in metasomatic veins (Fig. 4f). As indicated previously, the $\mathrm{Kd}^{\mathrm{amph} / \mathrm{liq}}$ for $\mathrm{TiO}_{2}$ appears to be primarily controlled by melt polymerization that, in turn, is related to the temperature of crystallization or more precisely the degree of differentiation, but seems, otherwise, independent of the composition of the liquid, i.e., silica undersaturated or saturated. Thus, the $\mathrm{Ti}$ contents of amphiboles at a fixed $\mathrm{Mg \#}$ should correlate with the $\mathrm{Ti}$ contents of coexisting liquids. Figure $4 \mathrm{~b}$ shows that amphiboles from metasomatic veins (on average) contain lower $\mathrm{TiO}_{2}$ contents for a given $\mathrm{Mg \#}$ than amphiboles produced in the FC experiments from an initial basanite (this study) or hawaiite (Nekvasil et al. 2004). This suggests that melts that produced these metasomatic veins are less $\mathrm{TiO}_{2}$-rich than both experimental liquids. We estimate the $\mathrm{TiO}_{2}$ content of metasomatic liquids that formed these amphiboles to vary between $\sim 3$ and $1.5 \mathrm{wt} \%$ (with an average of $\sim 2 \mathrm{wt} \%$ ) utilizing a value of $\mathrm{Kd}^{\mathrm{amph} / \mathrm{liq}}$ for $\mathrm{TiO}_{2}$ of 2 (Fig. 5a). Considering that the fractionation of anhydrous cumulates enriches residual liquid in $\mathrm{TiO}_{2}$, we infer that the initial "primitive" melts produced by mantlemelting contained even slightly lower $\mathrm{TiO}_{2}$ contents (Fig. 6b). Prytulak and Elliott (2007) infer that melts with a $\mathrm{TiO}_{2}$ content of $2 \mathrm{wt} \%$ could be generated by low-degree partial melting $(\sim 1 \%)$ of peridotite with a composition between depleted MORB mantle (DMM) (Workman and
Hart 2005) and primitive mantle (McDonough and Sun 1995). Therefore, the formation of hydrous metasomatic veins does not require the percolation of an initial $\mathrm{TiO}_{2}$ rich liquid such as basanite or nephelinite (liquids characterized by $\mathrm{TiO}_{2}$ content higher than $3 \mathrm{wt} \%$; Dasgupta and Hirschmann 2007), but could be explain by the percolation and differentiation of low degree of partial melts originating from slightly enriched peridotite (such as enriched E-DMM; Workman and Hart 2005).

Metasomatism as a consequence or as a precursor of alkaline magmatism

An open question regarding metasomatism is its relationship with associated alkaline magmas: is metasomatism a consequence of or a precursor of alkaline magmatism (Bailey 1982; Harte et al. 1993; Menzies 1983; Wilshire 1987)? The trace element distribution of continental or oceanic alkaline magmas is characterized by specific anomalies such as elevated $\mathrm{Nb} / \mathrm{Th}$ or $\mathrm{Ce} / \mathrm{Pb}$ ratios compared to MORB-type asthenospheric melts. However, the trace element contents computed from metasomatic minerals utilizing published partition coefficients, do not unequivocally resolve whether the initial metasomatic melts are themselves characterized by these anomalies or not. The principal reasons are: (1) the $\mathrm{Kd}^{\mathrm{min} / \mathrm{liq}}$ used for the calculation of the liquid compositions vary as functions of pressure, temperature and melt structure and composition; and (2) the fractionation of accessory minerals such as rutile, apatite, zircon, etc., during differentiation could significantly modify elemental ratios of the metasomatic melts relative to the primitive or primary liquids (O'Hara et al. 2001). Alkaline magmas show a wide range of composition encompassing $h y$-normative transitional alkali olivine basalt to nephelinites and FC experimental data suggest that all these liquids are able to generate anhydrous to hydrous cumulates by differentiation that resembles metasomatic vein assemblages. Therefore, the FC experimental studies cannot be employed to unequivocally confirm or refute the hypothesis that metasomatic veins are an initial product of alkaline magmatism, which sampled these early-formed veins in a second stage.

In order to address the question whether the metasomatism observed in lithospheric mantle is a precursor or a consequence of alkaline magmatism, it is essential to take into consideration the constraints related to the petrogenesis of alkaline magmas. Nephelinite and basanite are typical primitive rocks emitted in continental and oceanic intraplate volcanoes. However, their major and trace elements composition could not be produced directly by lowdegree partial melting of a MORB source, but requires specific source characteristics. (1) Assuming that alkaline rocks are formed by melting of a peridotite, Prytulak and 
Elliott (2007) indicate that the sources of alkaline magma need to be more enriched than primitive mantle to reproduce the observed $\mathrm{TiO}_{2}$ range by melting alone. This implies that an enrichment process in the source of intraplate alkaline basalt is a prerequisite to their generation. (2) Based on extrapolations of melting experiments on peridotite in the presence of 2.5 or $1 \mathrm{wt} \%$ of $\mathrm{CO}_{2}$, Dasgupta and Hirschmann (2007) suggest that the major element composition of highly ne-normative lavas could be produced only at low degree of partial melting $(\sim 1-5 \%)$ of a fertile peridotite source containing between 0.1 and $0.25 \mathrm{wt} \% \mathrm{CO}_{2}$. However, the effect of $\mathrm{H}_{2} \mathrm{O}$ in addition to $\mathrm{CO}_{2}$ on melt composition is not considered in their experimental study, and it is not clear if low-degree partial melting of peridotite with $\mathrm{CO}_{2}: \mathrm{H}_{2} \mathrm{O}$ ratio realistic for the Earth mantle $[2.5 \pm 1.5$ (Dixon et al. 1997) to $\sim 1(\mathrm{Au}-$ baud et al. 2005)] is able to produce nephelinite or basanite composition (Dasgupta and Hirschmann 2007).

An alternative interpretation suggests that such alkaline rocks are produced by melting of metasomatically modified lithosphere (Halliday et al. 1992, 1995; McKenzie and O’Nions 1995; Sun and McDonough 1989; Niu and O'Hara 2003; Panter et al. 2006; Pilet et al. 2004, 2008; Wass and Rogers 1980). In particular, Pilet et al. (2008) demonstrate that melting of hydrous metasomatic veins is able to explain the major- and trace-element characteristics of nephelinite/basanite magmas. The present experimental results support this second alternative by demonstrating (1) that the percolation and differentiation of a low-degree melt from a source similar to MORB mantle (DMM to E-DMM in composition) could produce hydrous cumulates similar in composition to the metasomatic veins considered by Pilet et al. (2008) as a potential source for alkaline magmas such basanite or nephelinite; and (2) that the initial (metasomatic) liquid produced in the mantle is not required to be highly ne-normative (circumventing the otherwise somewhat circular argument that alkaline liquids produce cumulates that form the source of alkaline magmas) but could perfectly be represented by hy-normative liquids (as for example produced by low to moderate degree of partial melting of peridotite).

\section{Summary and concluding remarks}

1. In this experimental study we determined the liquid line of descent starting from an initial, primitive, hydrous, basanitic liquid. The liquid line of descent evolves to peralkaline, silica-poor, aluminum-rich compositions. The high temperature cumulates $(1,250-$ $1,160^{\circ} \mathrm{C}$ ) are anhydrous assemblages of cpx + olivine dominated by cpx. At lower temperature, hydrous cumulates dominated by amphibole with some minor cpx, spinel, phlogopite, ilmenite, titanomagnetite and apatite $\left(1,130-980^{\circ} \mathrm{C}\right)$ are formed.

2. The comparison between FC experiments starting from an initial highly ne-normative liquid (basanite) with FC experiments from $h y$-normative initial compositions (hawaiite and picrobasalt) indicates that for all parental compositions, solid phases formed upon differentiation are rather similar even though their proportions vary significantly (olivine $+\mathrm{cpx}$ at high temperature, and amphibole $+\mathrm{cpx}$ at lower temperature). One significant difference distinguishing cumulates formed from initial $n e$ - and $h y$-normative melts, respectively, is the presence of opx in cumulates generated from hy-normative liquids. The presence of opx in metasomatic ultramafic lithologies observed in mantle outcrops or carried as xenoliths by alkaline basalts suggests that these lithologies could be produced by the percolation and differentiation of $h y$ normative liquids rather then by ne-normative ones as commonly assumed.

3. Temperature of amphibole appearance on the liquidus in the different FC experiments infers a liquid composition control on its appearance; in particular, the alkali content exerts a rather strong control on the relative stability of amphiboles as suggested by Sisson and Grove (1993). Furthermore, temperature or probably even more the polymerization of silicate liquid that are intimately linked together have a major effect on the $\mathrm{Kd}^{\mathrm{amph} / \mathrm{liq}}$ for $\mathrm{TiO}_{2}$; whereas pressure and mineral structure (and temperature to a lesser extent) control the $\mathrm{K}_{2} \mathrm{O}$ content of amphiboles.

4. A comparison of amphibole compositions produced in FC experiments from basanite, hawaiite and picrobasalt initial compositions with amphiboles from lithospheric veins or xenocrysts contained in alkaline lavas indicates that the formation of hydrous metasomatic veins could be explained by the percolation and differentiation of low-degree partial melts of slightly enriched peridotite (such as E-DMM; Workman and Hart 2005).

5. This study (2) supports the model suggesting the formation of anhydrous and hydrous metasomatic vein as a continuum polybaric differentiation process (Harte et al. 1993; Morris and Pasteris 1987; Nielson and Noller 1987; Nielson and Wilshire 1993; Wilshire 1987) and (2) infers that hornblendite veins (amphibole \pm cpx) proposed as a potential source for alkaline magmatism by Pilet et al. (2008) could indeed be formed by crystallization-differentiation of low-degree partial melts of peridotitic mantle similar to that observed in mid-ocean ridges. This conforms with the hypothesis that metasomatism is a precursor to alkaline magmatism as proposed by various authors (Halliday 
et al. 1992, 1995; McKenzie and O’Nions 1995; Niu and O'Hara 2003; Pilet et al. 2004, 2005, 2008; Sun and McDonough 1989; Wass and Rogers 1980), but it does not exclude that some metasomatic veins are the product of high-pressure differentiation of alkaline magmas similar to OIBs.

6. The different FC experimental studies considered in this contribution allowed to clarify the differentiation trend produced from different initial liquids. However, some parameters, in particular the effect of variable $\mathrm{H}_{2} \mathrm{O}$ and/or $\mathrm{CO}_{2}$ contents on the liquid differentiation trend, remain unconstrained. Thus, additional systematic studies of differentiation trends are required to rigorously constrain the formation of metasomatic veins within the mantle and their potential interactions with the surrounding mantle.

Acknowledgments We would like to acknowledge the thorough and constructive reviews and comments provided by Sigurdur Jakobsson, an anonymous reviewer and editor Jon Blundy that helped to improve this contribution. This work was supported by the Swiss National Science Foundation.

\section{References}

Alonso-Perez R, Muntener O, Ulmer P (2009a) Igneous garnet and amphibole fractionation in the roots of island arcs: experimental constraints on andesitic liquids. Contrib Mineral Petrol 157:541558. doi: 10.1007/s00410-008-0351-8

Alonso-Perez R, Ulmer P, Muntener O (2009b) Differentiation of a primary, hydrous, picrobasaltic, calc-alkaline magma: an experimental study at $1.5 \mathrm{GPa}$. Contrib Mineral Petrol (submitted)

Aoki KI (1970) Petrology of Kaersutite-bearing ultramafic and mafic inclusions in Iki-island, Japan. Contrib Mineral Petrol 25:270283

Aubaud C, Pineau F, Hékinian R, Javoy M (2005) Degassing of $\mathrm{CO}_{2}$ and $\mathrm{H}_{2} \mathrm{O}$ in submarine lavas from the Society hotspot. Earth Planet Sci Lett 235:511-527

Bailey DK (1982) Mantle metasomatism-continuing chemical change within the Earth. Nature 296:525-530

Baker DR, Eggler DH (1987) Compositions of anhydrous and hydrous melts coexisting with plagioclase, augite, and olivine or low-Ca pyroxene from $1 \mathrm{~atm}$ to $8 \mathrm{kbar}$-application to the Aleutian volcanic center of Atka. Am Mineral 72:12-28

Baker MB, Stolper EM (1994) Determining the composition of highpressure mantle melts using diamond aggregates. Geochim Cosmochim Acta 58:2811-2827

Basu AR (1978) Trace elements and Sr-isotopes in some mantlederived hydrous minerals and their significance. Geochim Cosmochim Acta 42:659-668

Best MG (1974) Mantle-derived amphibole within inclusions in alkalic-basaltic lavas. J Geophys Res 27:25-44

Bodinier JL, Guiraud M, Fabries J, Dostal J, Dupuy C (1987a) Petrogenesis of layered pyroxenites from the Lherz, Freychinede and Prades ultramafic bodies (Ariege, French Pyrenees). Geochim Cosmochim Acta 51:279-290

Bodinier JL, Fabries J, Lorand JP, Dostal J, Dupuy C (1987b) Geochemistry of amphibole pyroxenite veins from the Lherz and Freychinede ultramafic bodies (Ariege, French Pyrenees). Bull Mineral 110:345-358
Bodinier JL, Menzies MA, Shimizu N, Frey FA, McPherson E (2004) Silicate, hydrous and carbonate metasomatism at Lherz, France: contemporaneous derivatives of silicate melt-harzburgite reaction. J Petrol 45:299-320

Bohlen SR, Essene EJ, Boettcher AL (1980) Reinvestigations and applications of olivine-quartz-orthopyroxene barometry. Earth Planet Sci Lett 47:1-10

Bose K, Ganguly J (1995) Quartz-coesite revisited: reversed experimental determinations at 500-1000 degrees $\mathrm{C}$ and retrieved thermochemical properties. Am Mineral 80:231-238

Bowen NL (1914) The ternary system diopside-forsterite-silica. Am J Sci, 4th Series 33:551-573

Bowen NL (1928) The evolution of the igneous rocks. Princeton University Press, Princeton

Carmichael ISE, Nicholls J, Smith AL (1970) Silica activity in igneous rocks. Am Mineral 55:246-263

Conquere F (1971) Amphibole pyroxenites and amphibolites associated with lherzolites from Lherz-example of effect of water on fractionation of liquids derived from partial melting of lherzolites. Contrib Mineral Petrol 33:32-61

Conquere F (1977) Petrology of layered pyroxenites in ultramafic complexes from Ariege (France) and other occurrences of spinel lherzolites.1. Mineralogical and chemical compositions, evolution of physical equilibrium conditions. Bull Soc Franc Min Crist 100:42-80

Dasgupta R, Hirschmann MM (2007) Partial melting experiments of peridotite $+\mathrm{CO}_{2}$ at $3 \mathrm{GPa}$ and genesis of alkalic ocean island basalts. J Petrol 48:2093-2124

Dawson JB (1984) Contrasting types of upper-mantle metasomatism? In: Kornprobst J (ed) Kimberlites II: the mantle and crust-mantle relationships. Elsevier, Amsterdam, pp 289-294

Dawson JB, Smith JV (1982) Upper-mantle amphiboles-a review. Mineral Mag 45:35-46

Dawson JB, Smith JV (1988) Metasomatised and veined upper mantle xenoliths from Pello Hill, Tanzania: evidence for anomalouslylight mantle beneath the Tanzanian sector of the East African Rift Valley. Contrib Mineral Petrol 100:510-527

Dixon JE, Stolper EM, Holloway JR (1995) An experimental study of water and carbon dioxide solubilities in mid ocean ridge basaltic liquids.1. Calibration and solubility models. J Petrol 36:1607-1631

Dixon JE, Clague DA, Wallace P, Poreda R (1997) Volatiles in alkalic basalts from the North Arch volcanic field, Hawaii: extensive degassing of deep submarine-erupted alkalic series lavas. J Petrol 38:911-939

Falloon TJ, Green DH (1987) Anhydrous partial melting of MORB pyrolite and other peridotite compositions at $10 \mathrm{kbar}$-implications for the origin of primitive MORB glasses. Mineral Petrol $37: 181-219$

Falloon TJ, Danyushevsky LV, Green DH (2001) Peridotite melting at $1 \mathrm{GPa}$ : reversal experiments on partial melt compositions produced by peridotite-basalt sandwich experiments. J Petrol 42:2363-2390

Francis DM (1976) The origin of amphibole in lherzolite xenoliths from Nunivak Island, Alaska. J Petrol 17:357-378

Frey FA (1984) Rare earth abundances in upper mantle rocks. In: Henderson P (ed) Rare earth element geochemistry. Elsevier, Amsterdam, pp 153-203

Gaetani GA, Grove TL (1998) The influence of water on melting of mantle peridotite. Contrib Mineral Petrol 131:323-346

Gaetani GA, Grove TL, Bryan WB (1993) The influence of water on the petrogenesis of subduction-related igneous rocks. Nature 365:332-334

Gee LL, Sack RO (1988) Experimental petrology of melilite nephelinites. J Petrol 29:1233-1255

Gilbert C, Helz R, Popp R, Spear F (1982) Experimental studies of amphibole stability. In: Veblen D, Ribbe P (eds) Amphiboles: 
petrology and experimental phase relations. Reviews in mineralogy. Mineral Society of America, Washington, DC, pp 229346

Green TH, Ringwood AE (1968) Genesis of the calc-alkaline igneous rock suite. Contrib Mineral Petrol 18:105-162

Grove TL, Bryan WB (1983) Fractionation of pyroxene-phyric MORB at low-pressure-an experimental study. Contrib Mineral Petrol 84:293-309

Grove TL, Chatterjee N, Parman SW, Médard E (2006) The influence of $\mathrm{H}_{2} \mathrm{O}$ on mantle wedge melting. Earth Planet Sci Lett 249:74-89

Halliday AN et al (1992) Lead isotope evidence for young traceelement enrichment in the oceanic upper mantle. Nature 359:623-627

Halliday AN et al (1995) Incompatible trace-elements in OIB and MORB and source enrichment in the sub-oceanic mantle. Earth Planet Sci Lett 133:379-395

Harte B, Hunter RH, Kinny PD (1993) Melt geometry, movement and crystallization, in relation to mantle dykes, veins and metasomatism. Philos Trans R Soc Lond Ser A 342:1-21

Hirose K (1997a) Melting experiments on lherzolite KLB-1 under hydrous conditions and the generation of high-magnesian andesitic melts. Geology 25:42-44

Hirose K (1997b) Partial melt compositions of carbonated peridotite at $3 \mathrm{GPa}$ and role of $\mathrm{CO}_{2}$ in alkali-basalt magma generation. Geophys Res Lett 24:2837-2840

Hirose K, Kawamoto T (1995) Hydrous partial melting of lherzolite at $1 \mathrm{GPa}$ : the effect of $\mathrm{H}_{2} \mathrm{O}$ on the genesis of basaltic magmas. Earth Planet Sci Lett 133:463-473

Hirose K, Kushiro I (1993) Partial melting of dry peridotites at highpressures-determination of compositions of melts segregated from peridotite using aggregates of diamond. Earth Planet Sci Lett 114:477-489

Holloway JR, Pan V, Gudmundsson G (1992) High-pressure fluidabsent melting experiments in the presence of graphite: oxygen fugacity, ferric/ferrous ratio and dissolved $\mathrm{CO}_{2}$. Eur $\mathrm{J}$ Mineral $4: 105-114$

Irving A (1974) Pyroxene-rich ultramafic xenoliths in the Newer basalts of Victoria, Australia. Neues Jahrb Miner Abh 120:147167

Irving AJ (1980) Petrology and geochemistry of composite ultramafic xenoliths in alkalic basalts and implications for magmatic processes within the mantle. Am J Sci 280-A:389-426

Irving AJ, Frey FA (1984) Trace element abundance in megacrysts and their host basalts: constraints on partition coefficients and megacryst genesis. Geochim Cosmochim Acta 48:1201-1227

Jakobsson S, Holloway R (1986) Crystal-liquid experiments in the presence of a $\mathrm{C}-\mathrm{O}-\mathrm{H}$ fluid buffered by graphite + iron + wüstite: experimental method and near-liquidus relations in basanite. J Volcanol Geotherm Res 29:265-291

Jakobsson S, Oskarsson N (1994) The system C-O in equilibrium with graphite at high pressure and temperature: an experimental study. Geochim Cosmochim Acta 58:9-17

Kägi R (2000) The liquid line of descent of hydrous, primary, calcalkaline magmas under elevated pressure. An experimental approach. PhD thesis, ETH Zürich, pp 115

Kempton PD (1987) Metasomatism and enrichment in lithospheric peridotites. In: Menzies MA, Hawkesworth CJ (eds) Mantle metasomatism. Academic Press, London, pp 45-89

Kramers JD, Roddick JCM, Dawson JB (1983) Trace element and isotope studies on veined, metasomatic and "MARID" xenoliths from Bult Fontein, South Africa. Earth Planet Sci Lett 65:90106

Kushiro I, Mysen BO (2002) A possible effect of melt structure on the $\mathrm{Mg}-\mathrm{Fe}^{2+}$ partitioning between olivine and melt. Geochim Cosmochim Acta 66:2267-2272
Leake BE et al (1997) Nomenclature of amphiboles: report of the subcommittee on amphiboles of the International Mineralogical Association, commission on new minerals and mineral names. Am Miner 82:1019-1037

Lloyd FE, Bailey DK (1975) Light element metasomatism of the continental mantle: the evidence and the consequences. Phys Chem Earth 9:389-416

Longhi J (1991) Comparative liquidus equilibria of hypersthenenormative basalts at low-pressure. Am Miner 76:785-800

Lundstrom CC (2000) Rapid diffusive infiltration of sodium into partially molten peridotite. Nature 403:527-530

McDonough WF, Sun SS (1995) The composition of the earth. Chem Geol 120:223-253

McKenzie D (1989) Some remarks on the movement of small melt fractions in the mantle. Earth Planet Sci Lett 95:53-72

McKenzie D, O’Nions RK (1995) The source regions of ocean island basalts. J Petrol 36:133-159

McPherson E et al (1996) Geochemistry of metasomatism adjacent to amphibole-bearing veins in the Lherz peridotite massif. Chem Geol 131:135-157

Médard E, McCammon CA, Barr JA, Grove TL (2008) Oxygen fugacity, temperature reproducibility, and $\mathrm{H}_{2} \mathrm{O}$ contents of nominally anhydrous piston-cylinder experiments using graphite capsules. Am Mineral 93:1838-1844

Menzies MA (1983) Mantle ultramafic xenoliths in alkaline magmas: evidence for mantle heterogeneity modified by magmatic activity. In: Hawkesworth CJ, Norry MJ (eds) Continental basalts and mantle xenoliths. Shiva Publishing, Cheshire, UK, pp 92-110

Menzies MA, Murthy VR (1980) Nd and Sr isotope geochemistry of hydrous mantle nodules and their host alkali basalts: implications for local heterogeneities in metasomatically veined mantle. Earth Planet Sci Lett 46:323-334

Morimoto N (1988) Nomenclature of pyroxenes. Mineral Mag 52:535-550

Morris EM, Pasteris JD (1987) Mantle metasomatism and alkaline magmatism. Geol Soc Am Spec Paper 215

Muntener O, Ulmer P (2006) Experimentally derived high-pressure cumulates from hydrous arc magmas and consequences for the seismic velocity structure of lower arc crust. Geophys Res Lett 31:L21308

Muntener O, Kelemen PB, Grove TL (2001) The role of $\mathrm{H}_{2} \mathrm{O}$ during crystallization of primitive arc magmas under uppermost mantle conditions and genesis of igneous pyroxenites: an experimental study. Contrib Mineral Petrol 141:643-658

Nekvasil $\mathrm{H}$ et al (2004) The origin and evolution of silica-saturated alkalic suites: an experimental study. J Petrol 45:693-721

Neumann ER, Wulff-Pedersen E, Pearson NJ, Spencer EA (2002) Mantle xenoliths from Tenerife (Canary Islands): evidence for reactions between mantle peridotites and silicic carbonatite melts inducing Ca metasomatism. J Petrol 43:825-857

Neumann ER, Griffin WL, Pearson NJ, O'Reilly SY (2004) The evolution of the upper mantle beneath the Canary Islands: information from trace elements and $\mathrm{Sr}$ isotope ratios in minerals in mantle xenoliths. J Petrol 45:2573-2612

Nielsen RL, Dungan MA (1983) Low-pressure mineral-melt equilibria in natural anhydrous mafic systems. Contrib Mineral Petrol $84: 310-326$

Nielson JE, Noller JS (1987) Processes of mantle metasomatism: constraints from observations of composite peridotite xenoliths. In: EM Morris and JD Pasteris (eds) Mantle metasomatism and alkaline magmatism. Geol Soc Am Spec Paper, pp 61-76

Nielson JE, Wilshire HG (1993) Magma transport and metasomatism in the mantle: a critical review of current geochemical models. Am Mineral 78:1117-1134 
Niu YL, O’Hara MJ (2003) Origin of ocean island basalts: a new perspective from petrology, geochemistry, and mineral physics considerations. J Geophys Res 108(B4):2209

O'Hara MJ (1968) Bearing of phase equilibria studies in synthetic and natural systems on origin and evolution of basic and ultrabasic rocks. Earth Sci Rev 4:69-133

O'Hara MJ, Fry N, Prichard HM (2001) Minor phases as carriers of trace elements in non-modal crystal-liquid separation processes II: illustrations and bearing on behaviour of REE, U, Th and the PGE in igneous processes. J Petrol 42:1887-1910

Panter KS, Blusztajn J, Hart SR, Kyle PR, Esser R, McIntosh WC (2006) The origin of HIMU in the SW Pacific: evidence from intraplate volcanism in southern New Zealand and subantarctic islands. J Petrol 47:1673-1704

Pilet S, Hernandez J, Villemant B (2002) Evidence for high silicic melt circulation and metasomatic events in the mantle beneath alkaline provinces: the $\mathrm{Na}-\mathrm{Fe}$-augitic green-core pyroxenes in the tertiary alkali basalts of the Cantal massif (French Massif Central). Mineral Petrol 76:39-62

Pilet S, Hernandez J, Bussy F, Sylvester PJ (2004) Short-term metasomatic control of $\mathrm{Nb} / \mathrm{Th}$ ratios in the mantle sources of intraplate basalts. Geology 32:113-116

Pilet S, Hernandez J, Sylvester P, Poujol M (2005) The metasomatic alternative for ocean island basalt chemical heterogeneity. Earth Planet Sci Lett 236:148-166

Pilet S, Baker MB, Stolper EM (2008) Metasomatized lithosphere and the origin of alkaline lavas. Science 20:916-919

Prytulak J, Elliott T (2007) $\mathrm{TiO}_{2}$ enrichment in ocean island basalts. Earth Planet Sci Lett 263:388-403

Ray GL, Shimizu N, Hart SR (1983) An ion microprobe study of the partitioning of trace elements between clinopyroxene and liquid in the system diopside-albite-anorthite. Geochim Cosmochim Acta 47:2131-2140

Roeder PL, Emslie RF (1970) Olivine-liquid equilibrium. Contrib Mineral Petrol 29:275-289

Sack RO, Carmichael ISE, Rivers M, Ghiorso MS (1980) Ferricferrous equilibria in natural silicate liquids at 1 bar. Contrib Mineral Petrol 75:369-376

Sauerzapf A, Lattard D, Burchard M, Engelman R (2008) The titanomagnetite-ilmenite equilibrium: new experimental data and thermo-oxybarometric application to the crystallization of basic to intermediate rocks. J Petrol 49:1161-1185

Shaw CSJ (1999) Dissolution of orthopyroxene in basanitic magma between 0.4 and $2 \mathrm{GPa}$ : further implications for the origin of $\mathrm{Si}$ rich alkaline glass inclusions in mantle xenoliths. Contrib Mineral Petrol 135:114-132

Shaw CSJ, Thibault Y, Edgar AD, Lloyd FE (1998) Mechanisms of orthopyroxene dissolution in silica-undersaturated melts at 1 atmosphere and implications for the origin of silica-rich glass in mantle xenoliths. Contrib Mineral Petrol 132:354-370

Sisson T, Grove T (1993) Experimental investigations of the role of $\mathrm{H} 2 \mathrm{O}$ in calc-alkaline differentiation and subduction zone magmatism. Contrib Mineral Petrol 113:143-166

Sobolev AV, Hofmann AW, Sobolev SV, Nikogosian IK (2005) An olivine-free mantle source of Hawaiian shield basalts. Nature 434:590-597

Sun SS, McDonough WF (1989) Chemical and isotopic systematics of oceanic basalts; implications for mantle composition and processes. In: Saunders AD Norry MJ (eds) Magmatism in the ocean basins. Geol Soc Spec Publ, pp 313-345
Tiepolo M, et al. (2000) Partitioning of rare earth elements, Y, Th, U, and $\mathrm{Pb}$ between pargasite, kaersutite, and basanite to trachyte melts: implications for percolated and veined mantle. Geochem Geophys Geosyst 1:8. doi:10.1029/2000GC000064(8)

Ulmer P (1989) High pressure phase equilibria of a calc-alkaline picro-basalt: implications for the genesis of calc-alkaline magmas. Carnegie Inst Wash Yearb 88:28-35

Ulmer P, Luth RW (1991) The graphite-COH fluid equilibrium in $P$, $T$, $f \mathrm{O}_{2}$ space. An experimental determination to $30 \mathrm{kbar}$ and $1600^{\circ} \mathrm{C}$. Contrib Mineral Petrol 106:265-272

Varne R (1970) Hornblende lherzolite and the upper mantle. Contrib Mineral Petrol 27:45-51

Vaselli O et al (1995) Ultramafic xenoliths in pliopleistocene alkali basalts from the eastern transylvanian basin-depleted mantle enriched by vein metasomatism. J Petrol 36:23-53

Villiger S, Ulmer P, Muntener O, Thompson AB (2004) The liquid line of descent of anhydrous, mantle-derived, tholeiitic liquids by fractional and equilibrium crystallization-an experimental study at 1.0 GPa. J Petrol 45:2369-2388

Walter MJ (1998) Melting of garnet peridotite and the origin of komatiite and depleted lithosphere. J Petrol 39:29-60

Wass SY, Rogers NW (1980) Mantle metasomatism-precursor to continental alkaline volcanism. Geochim Cosmochim Acta 44:1811-1823

Wasylenki LE, Baker MB, Kent AJR, Stolper EM (2003) Nearsolidus melting of the shallow upper mantle: partial melting experiments on depleted peridotite. J Petrol 44:1163-1191

Wilshire HG (1987) A model of mantle metasomatism. In: Morris EM, Pasteris JD (eds) Mantle metasomatism and alkaline magmatism. Geol Soc Am Spec Paper, pp 47-60

Wilshire HG, Trask NG (1971) Structure and textural relationships of amphibole and phlogopite inclusions, Dish Hill, California. Am Miner 56:240-255

Wilshire HG, Pike JEN, Meyer CE, Schwarzman E (1980) Amphibole-rich veins in lherzolite xenoliths, Dish Hill and Deadman Lake, California. Am J Sci 280-A:576-593

Wilson M, Downes H, Cebria JM (1995) Contrasting fractionation trends in coexisting continental alkaline magmas series; Cantal, Massif Central, France. J Petrol 36:1729-1753

Woodland AB, Kornprobst J, McPherson E, Bodinier J-L, Menzies MA (1996) Metasomatic interactions in the lithospheric mantle: petrologic evidence from the Lherz massif, French Pyrenees. Chem Geol 134:83-112

Workman RK, Hart SR (2005) Major and trace element composition of the depleted MORB mantle (DMM). Earth Planet Sci Lett 231:53-72

Wulff-Pedersen E, Neumann ER, Vannucci R, Bottazzi P, Ottolini L (1999) Silicic melts produced by reaction between peridotite and infiltrating basaltic melts: ion probe data on glasses and minerals in veined xenoliths from La Palma, Canary Islands. Contrib Mineral Petrol 137:59-82

Yagi K, Onuma K (1967) The joint $\mathrm{CaMgSi}_{2} \mathrm{O}_{6}-\mathrm{CaTiAl}_{2} \mathrm{O}_{6}$ and its bearing on titanaugites. J Fac Sci Hokkaido Univ Ser 4 13:463-483

Yaxley GM, Green DH (1998) Reactions between eclogite and peridotite: mantle refertilisation by subduction of oceanic crust. Schweiz Mineral Petrogr Mitt 78:243-255

Zanetti A, Vannucci R, Bottazzi P, Oberti R, Ottolini L (1996) Infiltration metasomatism at Lherz as monitored by systematic ion microprobe investigations close to a hornblendite vein. Chem Geol 134:113-133 